\title{
CAPTAIN JACQUES MARGERET: A REMARKABLE HUGUENOT SOLDIER IN RUSSIA'S TIME OF TROUBLES ${ }^{1}$
}

\author{
Chester S. L. Dunning \\ Texas A\&M University, College Station, Texas, United States of America
}

\begin{abstract}
Captain Jacques Margeret (fl. 1591-1621), a brave and highly intelligent French Huguenot soldier, was an active observer-participant in the Time of Troubles who contributed to Russia's military modernization. Margeret also wrote one of the most valuable foreign accounts of early modern Russia: Estat de l'Empire de Russie et Grand Duché de Moscovie (1607). In this essay, Chester Dunning surveys two hundred years of scholarship about Margeret and his famous book, and he lays the foundation for a more objective biography of the remarkable French captain who served Tsar Boris Godunov, Tsar "Dmitrii", Tsar Vasilii Shuiskii, the Tushinite pretender Dmitrii, "Tsar" Wladyslaw, King Sigismund III of Poland-Lithuania, Prince Janusz Radziwiłł, and finally King Gustav II Adolf of Sweden. This essay challenges recent scholarship concerning Margeret's identity, his religious affiliation, his early career in France, his controversial career in Russia, his later career, and the composition of his book. This essay is based on fifty years of research by the translator of Jacques Margeret's book into English as The Russian Empire and Grand Duchy of Muscovy: A 17 $7^{\text {th }}$-Century French Account (1983). In addition to reading most published sources and scholarship about Margeret and his account of Russia, the author has examined documents related to Margeret's biography in French, Russian, Polish, and British archives. In the process, Dunning discovered a letter Margeret wrote to King James I in 1612 encouraging English military intervention in north Russia to counter Polish and Swedish intervention.

Key words: Jacques Margeret, Huguenots, mercenary soldiers, Boris Godunov, Dobrynichi, Tsar Dmitrii, Tushino, Klushino, Dmitrii Pozharskii, Janusz Radziwiłł, James I, Estat de l’Empire de Russie.

Citation. Dunning Ch.S.L. Captain Jacques Margeret: a Remarkable Huguenot Soldier in Russia's Time of Troubles. Vestnik Volgogradskogo gosudarstvennogo universiteta. Seriya 4, Istoriya. Regionovedenie. Mezhdunarodnye otnosheniya [Science Journal of Volgograd State University. History. Area Studies. International Relations], 2019, vol. 24, no. 2, pp. 76-102. DOI: https://doi.org/10.15688/jvolsu4.2019.2.8
\end{abstract}

УДК 94(470)“16”:347.176

Дата поступления статьи: 25.09.2018

ББК 63.3(2)44-3

Дата принятия статьи: 14.03.2019

\section{КАПИТАН ЖАК МАРЖЕРЕТ - ВЫДАЮЩИЙСЯ ГУГЕНОТСКИЙ СОЛДАТ СМУТНОГО ВРЕМЕНИ В РОССИИ ${ }^{1}$}

\author{
Честер С. Л. Даннинг \\ Техасский университет А\&M, г. Колледж-Стейшен, Техас, Соединенные Штаты Америки
}

Аннотация. Капитан Жак Маржерет (в период его деятельности с 1591 по 1621 г.), храбрый и очень умный французский гугенотский солдат, был активным наблюдателем-участником Смутного времени, который внес вклад в военную модернизацию России. Маржерет также является автором одной из наиболее ценных зарубежных публикаций о современном ему периоде истории России - «Состояние Российской 
империи и Великого княжества Московии» (1607). В данной статье автор рассматривает двухсотлетний опыт исследований, посвященных Маржерету и его знаменитой книге, и закладывает основу для более объективной биографии замечательного французского капитана, который служил царю Борису Годунову, царю «Дмитрию», царю Василию Шуйскому, претенденту на трон тушинскому «Дмитрию», «царю» Владиславу, польсколитовскому королю Сигизмунду III, гетману Янушу Радзивиллу и, наконец, королю Швеции Густаву II Адольфу. Эта работа ставит под сомнение недавние наблюдения, касающиеся личности Маржерета, его религиозной принадлежности, ранней карьеры во Франции, неоднозначной карьеры в России, более поздней карьеры и состава его книги. Данная статья основана на пятидесятилетних исследованиях переводчика книги Жака Маржерета на английский язык «Российская империя и Великое княжество Московское: французское повествование 17-го века» (1983). В дополнение к большинству опубликованных источников и научных работ о Маржерете и его сочинении о России автор изучил документы, связанные с биографией Маржерета во французском, русском, польском и британском архивах. В ходе этой работы автор статьи обнаружил письмо, которое Маржерет написал королю Джеймсу I в 1612 г., призывающее английскую военную интервенцию на севере России противостоять польской и шведской интервенции.

Ключевые слова: Жак Маржерет, гугеноты, наемные солдаты, Борис Годунов, Добрыничи, Лжедмитрий, Тушино, Клушино, Дмитрий Пожарский, Януш Радзивилл, Джеймс I, «Состояние Российской империи».

Цитирование. Даннинг Ч. С. Л. Капитан Жак Маржерет - выдающийся гугенотский солдат Смутного времени в России // Вестник Волгоградского государственного университета. Серия 4, История. Регионоведение. Международные отношения. - 2019. - Т. 24, № 2. - С. 76-102. - (На англ.) - DOI: https://doi.org/ 10.15688/jvolsu4.2019.2.8

One of the most valuable foreign accounts of early modern Russia was written by Captain Jacques Margeret (fl. 1591-1621), a brave and highly intelligent French soldier who was an active observer-participant in Russia's Time of Troubles. Margeret's book, Estat de l'Empire de Russie et Grand Duché de Moscovie, was published in 1607 by command of King Henri IV [69; 70]. As the first printed French eyewitness account of Russia, Margeret's book played an important role in acquainting the French reading public with Muscovite Russia and in helping scholars make sense out of the Time of Troubles [21, vol. 14, p. 450-467, 490-504; 38; 67, p. 430-432; 108, livre 1 [1605], p. 41-55 (v); livre 2 [1606], p. $152-158(\mathrm{v})]$.

The first Russian historian to make extensive use of Margeret's unique information was Nikolai Karamzin [51, p. 378-379; 52]. It was Karamzin's use of Margeret as a source in Istoriia gosudarstva rossiiskogo that prompted Aleksandr Pushkin to acquire a copy of Margeret's book and to make the French captain a character in his play, Boris Godunov [30, p. 67, 71, 100, 102, 107, 151-152, 209, 406-409, 495, notes 201-202]. Due to Karamzin's influence, Margeret's book became one of the first foreign accounts to be translated into Russian. Nikolai Ustrialov published his translation in 1830, and it was used by several generations of Russian and Soviet historians ${ }^{2}$. Unfortunately, Ustrialov's
French was not up to the task, and he also mistranslated (or deleted) controversial passages in order to be politically correct in Tsar Nikolai I's Russia. The deficiencies of Ustrialov's translation went largely unnoticed until the late twentieth century, resulting in errors in Russian and Soviet historical scholarship [38, p. 360-369; 73, p. 105, note $98 ; 77$, p. $19-20 ; 128$, p. 210, note 5].

Napoleon's invasion of Russia was still a fresh memory in 1830 when Ustrialov praised Margeret's book as a valuable source but called Captain Margeret a "typical bloodthirsty French Catholic," referring to the French officer's controversial second tour of duty in Russia (16091611) $[78$, p. xiii, xix-x]. By the time the third edition of Ustrialov's translation appeared in 1859 , however, Ustrialov's assessment of Margeret had changed dramatically. Influenced by warming Franco-Russian relations after the Crimean War, Ustrialov referred to Margeret as a hero even while in Polish service during the Moscow uprising of March 1611 [123, vol. 1, p. 240-241]. He also praised Margeret's balanced portrayal of Russia's absolute monarchy. Ustrialov's high opinion of the Frenchman had a significant effect on the use of Margeret's evidence by other historians, who stopped complaining about Margeret's Polish service and concentrated on using his valuable evidence. Still referring to him as a Catholic, they praised Margeret and his book [1, s. 20; 55, p. 20; 58 , p. $7 ; 98$, p. $193 ; 99$, p. $29 ; 127$, p. 425]. By the 
time the fourth edition of Ustrialov's translation appeared in 1913, Margeret was being portrayed positively by Russian historians and his book had become a minor classic $[79, \text { p. 5-6 }]^{3}$.

Sergei Platonov (1860-1933), probably the greatest historian of the Time of Troubles, made extensive use of Margeret's unique evidence and praised him: "A master not only of the sword and musket but of the pen as well, he has left us with a fascinating description of events and institutions in Moscow." Platonov understood that Margeret's account of the "most memorable and tragic" events in Russia from 1590 to 1606 was a valuable narrative of the first phase of the Time of Troubles, the period of dynastic crisis that began with Tsarevich Dmitrii's "death" in Uglich in 1591 and ended with the assassination of Tsar Dmitrii in $1606[99$, p. $29,37,48 ; 100$, p. 86, 218, 253-254, 292-293, 295-296, 559, 561; 101, p. 67-68, 85-91]. Platonov's model of the Time of Troubles became extremely influential, but after the Russian Revolution his enthusiasm for Margeret was met with skepticism by early Soviet historians. Although Academician Platonov became a leading historian in the U.S.S.R. in the 1920s, he lost favor in the Stalin era and was forced into internal exile, where he died in $1933^{4}$. Shortly after Platonov was silenced, Captain Margeret was denounced as a "typical Polish henchman," and the value of his book was downgraded [11, p. 100; 26, p. 490; 56 , p. $35 ; 82$, p. 193, 195]. Nevertheless, Soviet historians still depended heavily on Margeret's eyewitness testimony $[57$, p. $231,253-254 ; 115$, p. 368-369]. In a major study of Margeret's career published in 1959, Givi Zhordaniia denounced him as a "typical adventurer" and "Polish agent" who actively supported Polish efforts to conquer Russia during the period 1610-1619 [130, p. 247, 311]. Unfortunately, Zhordaniia used sources poorly and was utterly confused by Margeret's activities after his departure from Russia in 1611 [38, p. 364; 130, p. 293-379]. During the post-Stalin era, Soviet scholars continued to use Margeret's unique information, but they frequently expressed dissatisfaction with him for not sharing their views about the nature of popular unrest during Russia's "First Peasant War" [4, p. 8, 11-12, 28-35; 38, p. 363-369; 57, p. 231, 253-254; 130, p. 239-279].

In the late twentieth century, Soviet and American scholars significantly advanced our understanding of Captain Margeret and his account of Russia. In 1982 Iurii Limonov published a fairly accurate Russian translation of Margeret's book with an excellent introduction and brief but useful notes. Limonov carefully examined Margeret's life and challenged the long-held assumption that he was a Catholic. Limonov made a good case for Margeret having been a Huguenot, a French Protestant [77, p. 14-19, 31-41]. In 1983 I published the first English translation of Margeret's book and made a good case for Margeret having been a Huguenot [35, p. 335336; 38, p. 369-370; 73, p. xvi, 97, note20]. In 1989 I published a letter Margeret wrote to King James I of England in 1613. That letter clearly shows that Margeret was a Protestant who strongly opposed Catholic Poland's attempt to conquer Russia [31;32].

In the early twenty-first century, Russian and Western scholars continue to study Jacques Margeret's biography, and they have made some important discoveries [9; 89]. Historians of Russia and scholars from a variety of disciplines continue to mine Margeret's book for unique information [17; $50 ; 53 ; 59 ; 64 ; 103 ; 109]$. The most notable recent contribution to the study of Margeret and his book was the publication in 2007 of Sostoianie rossiiskoy imperii: Zh. Marzheret $v$ dokumentakh $i$ issledovaniiakh, edited by André Berelowitch, V.D. Nazarov, and P.Iu. Uvarov [80]. This ambitious work, the product of international collaborative research, includes an accurate Russian translation of Margeret's text along with excellent annotation, a detailed examination of Margeret's historical evidence, and a study of the French captain's complicated and controversial career. Also included are copies of many documents related to Margeret's biography that greatly facilitate tracking his career, evaluating his actions, and using his evidence. The new Russian edition of Margeret's account received positive reviews, and it significantly advances the study of the formidable Frenchman ${ }^{5}$. Unfortunately, the scholarly apparatus of Sostoianie rossiiskoy imperii contains many errors and misinterpretations that distort Margeret's biography and complicate the task of interpreting his unique evidence. The purpose of this essay is to review what is known about Jacques Margeret's life in order to dispel confusion about him and to help future historians make more sophisticated use of his remarkable book. 
Jacques Margeret was born circa 1570 into one of the oldest known families of Auxonne, a royal county located on the eastern border of France between Burgundy and Habsburgcontrolled Franche-Comté. The Margeret family's history provides a classic example of the rise of the bourgeoisie in early modern France. In the sixteenth century the Margerets produced many respectable merchants, mayors, magistrates, and soldiers. A few members of the family managed to become non-hereditary robe nobles. In the seventeenth century the Margerets continued to prosper and produced several robe nobles. During the reign of King Louis XIV (r. 1643-1715), two members of the Margeret family finally succeeded in gaining entry into France's hereditary sword nobility [9, p. 302313; 27, p. 157; 71, p. ii-iv]. Jacques Margeret's grandfather, Pierre Margeret, was a Huguenot who became a prosperous merchant in Dijon by the 1560s. Pierre sired six children, including Jacques's father Guillaume [9, p. 303, 307; 27, p. $126-127 ; 71$, p. iii-iv]. Guillaume Margeret was a Huguenot who became a wealthy jewel merchant and traveled to Persia twice $[9$, p. 303 $305,309-310,314 ; 27$, p. 204 , note $15 ; 80$, p. 448 ; 130 , p. 247]. Guillaume's younger brother, Chrétien Margeret, also a Huguenot, served as a magistrate in the Chambre des Comptes of Dijon (the sovereign court of accounts for Burgundy). He became a rich and powerful robe noble in service to King Henri IV (r. 1589-1610) $[9$, p. $307-311 ; 27$, p. $112-114,118,127,157 ; 71$, p. iii-iv].

Guillaume Margeret married Jehanne Bynet, and their two children, Jacques and Marie, grew up in a comfortable bourgeois household [9, p. 303-305, 309]. Jacques received a very good education. He was fluent in French and German, and he studied Latin $[9$, p. 313, 320; 19, p. 54; 67, p. 429 ; 69, p. Aii-Aiii, 9, 16-16(v), 51; 73, p. 85, 187 , note $333 ; 82$, p. $118 ; 130$, p. 248-249]. Jacques became a good, if not inspired, writer. His study of the Russian empire is filled with the spirit of the French Renaissance, and it shows his awareness of classical literature, the Bible, and ideas of such giants of the French Renaissance as Montaigne and Jean Bodin [9, p. 313, 320-321; 73 , p. $\mathrm{xxx}$. Jacques may have received training in finance and trade as a youth. His family background and later activities make that seem likely. His book is filled with details about the Russian economy, foreign trade, finances, the tsar's treasury, and pearls worn by the Russian elite. While in Russian service Jacques became an associate of John Merrick, chief agent of the Muscovy Company, and throughout his life Jacques wrote letters and intelligence reports, handled complex finances, and maintained an interest in the fur trade [13, p. 91-94, 124-125; 32 , p. $98-99$; 71, p. xix-xxvi; 73, p. xxiii; 104, vol. 14, p. 225-226]. Nevertheless, growing up in the tumultuous era of the French Wars of Religion, Jacques quite naturally studied the profession of arms, which was to be his main occupation for thirty years.

When King Henri III was assassinated in 1589, the French throne devolved to the Protestant Henri of Navarre who founded the Bourbon dynasty as King Henri IV. The immediate reaction of many French Catholics to the accession of a Protestant king was to join the Catholic League that openly challenged Henri's authority, triggering a destructive civil war. All the important towns of Burgundy quickly joined the Catholic League. Only a relatively small number of Burgundians, many of them Huguenots, resisted. Magistrates supporting Henri IV were persecuted, forced out of Dijon, and had their possessions confiscated. Jacques's uncle, Chrétien Margeret, lost his house, and his wife and daughter were imprisoned by the Catholic League [9, p. 308-309; 29, p. 340341,$413 ; 54$, p. 243-244]. Supporters of the king set up a royalist counter-government in the strategically located town of Saint-Jean-de-Losne, converting it into a formidable base for military operations against the Catholic League.

Chrétien Margeret actively sought foreign loans to support the cause of King Henri IV. In 1591 Chrétien traveled to Germany and the Swiss cantons seeking funds. $\mathrm{He}$ was accompanied by his nephew Jacques Margeret. They returned to France later that year and headed straight for Saint-Jean-de-Losne. There the newly promoted robe noble Chrétien Margeret played an important role in the royalist countergovernment. King Henri gave Chrétien the task of collecting the salt tax (gabelle) across much of France, which he did with such zeal that the cost of salt rose dramatically. The king was pleased with Chrétien's faithful service, and that accelerated his career $[9$, p. 308,$310 ; 27$, p. 51- 
52, 112-114, 118]. Chrétien Margeret's nephew Jacques joined royalist military forces being organized in Saint-Jean-de-Losne by Philippe Baillet, lord of Vaugrenant. One of the fifty intrepid men of arms chosen to form the mainstay of the town's defense was Jacques Margeret. Despite repeated efforts by the Catholic League to capture Saint-Jean-de-Losne, its sturdy fortifications and energetic defense by the royalists proved too difficult to overcome. Serving under Vaugrenant, Jacques also fought elsewhere in Burgundy and participated in raiding parties to procure food and harass the enemy. Saint-Jean-de-Losne became the "terror" of the Catholic League in Burgundy [9, p. 317-319; 27, p. $126-127 ; 54$, p. 244-347; 69, p. Aii(v); 71, p. iv-v, xxx; 73, p. 4; 130, p. 247].

Other soldiers from the Margeret family also joined the king's cause. A Protestant "Captain Margeret" led a force of fifty royalists who fought against the Catholic League in Burgundy. It has been suggested that this "Captain Margeret" was none other than Jacques [9, p. $319 ; 85$, p. 478]. That is not true. Jacques was too young and served under Vaugrenant. It is more likely that this "Captain Margeret" was the same Huguenot Captain Margeret who was mentioned in a document from $1586[9$, p. 310; 28, p. 319, note 2]. Two of Jacques's cousins, Robert and Claude Margeret, fought for the king at Saint-Jean-deLosne and other places in Burgundy. Robert Margeret died during a siege of the royalist headquarters in 1593. Claude Margeret, born in 1577, was just eighteen years old when Henri IV invaded Burgundy in 1595 and achieved a decisive victory over a larger Spanish army. During that battle Claude's zeal and skill so impressed the king that he awarded the young man a sword, a very high honor. Claude Margeret went on to become a captain of mercenary soldiers and a "military entrepreneur" in service to Prince Maurice of Nassau, the stadtholder of the Dutch Republic and a brilliant innovator of military tactics [9, p. 311]. The family of Jacques Margeret fought valiantly for Henri IV for several years. After the king achieved his great victory over the Spanish army in June 1595, he generously rewarded his faithful supporters. By July 1595 royalist officials, including Chrétien Margeret, were back in control in Dijon [27, p. 52; 71, p. iiiv]. The civil war quickly died down, and Jacques Margeret soon found himself unemployed.
During the Thirteen Years' War (1593-1606), the Holy Roman emperor and his allies challenged Ottoman imperialism, and they welcomed French Huguenot soldiers with open arms. Enthusiastic reports of the progress of imperial troops against the Turks circulated widely in Europe in 1595, and many French soldiers joined the "crusade" [9, p. $320 ; 15$, vol. 1 , p. 1201]. In late 1595 or very early 1596 Jacques Margeret headed to Southeastern Europe to find work fighting against the Ottoman Empire ${ }^{6}$ [69, p. Aii-Aii(v); 73, p. 4]. Huguenot soldiers fought bravely alongside Catholics against the Turks. Huguenots were renowned as exceptionally good combat troops, and they distinguished themselves in foreign armies as skilled and honest warriors. Huguenots were zealous in battle, and they spread knowledge of new military tactics geared to gunpowder warfare. In many ways Huguenot soldiers helped professionalize the armies they served in [45, p. 5$6,19,231,243 ; 84$, p. $3,8-9,26-27$; 120 , p. 153155, 190-191]. Jacques Margeret joined the service of Prince Sigismund Bathory of Transylvania (r. 1581-1601), and then he joined the service of the Holy Roman Emperor Rudolph II (r. 1576-1612) in Hungary [69, p. iiii(v); 73, p. 4]. Transylvania and Hungary were both friendly to Huguenots. Jacques may have participated in the combined operations of the Habsburg and Transylvanian armies leading up to the battle of Keresztes in $1596^{7}$; he mentions the battle in his book [84, p. 9-10, 19, 26-27].

After fighting in Southeastern Europe, Margeret entered the service of King Sigismund III (r. 1587-1632) of Poland-Lithuania and received command of a company of infantry [69, p. ii(v); 73, p. 4]. Margeret left Polish service before King Sigismund, a fanatic Catholic, launched an invasion of Lutheran Sweden in 1598. As a Huguenot mercenary soldier, Margeret was willing to serve Catholic kings, but he was unwilling to help a Catholic king conquer a Protestant country. Margeret returned to Germany, possibly to Habsburg territory, but without reentering imperial service. Instead, he was recruited into Russian service by Afanasii Vlas'ev, Tsar Boris's diplomatic envoy on a mission to the Holy Roman emperor. Vlasyev was impressed by Captain Margeret whose time in Eastern Europe had given him valuable experience as a military officer and some knowledge of Slavic 
languages. Margeret's fluency in German, the common language of the foreign troops in tsarist service, was also an important factor in Vlas'ev's decision to hire him. Margeret arrived in Russia in 1600, and his first tour of duty there lasted six years [42, p. 102, 109-112, 115-118, 125-126; 71, p. v, xxx; 83, p. 266-267; 130, p. 247-249].

I have studied Jacques Margeret for forty years, and I thought I knew him well. But according to André Berelowitch, one of the editors of Sostoianie rossiiskoy imperii, almost everything I think I know is wrong. It was a truly bizarre experience for me to read Berelowitch's essay, "Kapitan Marzheret vo frantsuzskikh arkhivakh" [8] Berelowitch claims that the Captain Margeret who served in Russia from 1600 to 1606 and then published Estat de l'Empire de Russie was not Jacques Margeret, but was instead his cousin Étienne Margeret from the Catholic branch of the family. Étienne's father, Antoine Margeret, and his grandfather, Charles Margeret, were both Catholics. Berelowitch suspects that Étienne was also a Catholic or was simply indifferent to religion. Berelowitch asserts that it was Étienne who accompanied Chrétien Margeret to Germany in 1591. Instead of returning to France to fight for Henri IV, Étienne supposedly deserted his king at a critical time and headed for Southeastern Europe to fight the Turks. Berelowitch believes that Étienne Margeret never served in Saint-Jean-de-Losne, contradicting the claim Captain Margeret made in his book [8, p. 453-454, 457-460; 69, p. Aii(v); 73, p. 4]. According to Berelowitch, when Étienne returned to France from Russia in 1606 and presented himself to Henri IV, he brazenly lied about having fought for the king in the civil war. In other words, the preface to Henri in Estat de l'Empire de Russie was nothing but a hoax to promote the career of Étienne Margeret.

There is no evidence to support such fantastic claims about Captain Margeret's identity, and Berelowitch seems unsure of his own conclusions [8, p. 449, 457-458]. There are, in fact, a host of problems with Berelowitch's hypothesis, starting with direct evidence that the author of Estat de l'Empire de Russie was named Jacques, not Étienne ${ }^{8}$; that Captain Margeret's father was named Guillaume, not Antoine ${ }^{9}[8$, p. $457-458 ; 80$, p. $265-268,271-273 ; 111$, col. 235 , 243 ; 112 , col. $116 ; 130$, p. 247,285$]$; that his grandfather was named Pierre, not Charles [8, p. 468 , note 2 ; 71, p. iii-iv; 80 , p. 465-466]; and that all three of them were Huguenots, not Catholics [9, p. 303-404, 309; 13, p. 91-98, 123; 27 , p. $112-114,118,126-127,157$; 32, p. 96, 104105 ; 35 , p. 335 , note $21 ; 38$, p. 369-370; 71, p. iiiiv, xix-xxvi; 73, p. xvi, 97, note 20; 98, p. 182-194]. There is also no reason to doubt that Jacques fought for his king until 1595. Berelowitch's more cautious co-editor, V.D. Nazarov, rejected the conjectural identification of Captain Margeret as Jacques's Catholic cousin. Nazarov acknowledged that Jacques Margeret was a Huguenot and the author of Estat de l'Empire de Russie, but he accepted enough of Berelowitch's reasoning to argue that Jacques must have served only briefly at SaintJean-de-Losne [85, p. 477-478; 80, p. 465-466].

What led Berelowitch to such startling and wrong-headed conclusions? It turns out to be a combination of three things: the sub-title of Margeret's book and two documents Berelowitch studied in Bibliothèque Nationale: a short note written in 1668 and the dossier prepared in 1699 by two members of the Margeret family seeking promotion into the hereditary sword nobility [8, p. 446-465]. When Jacques Margeret chose the title for his book, he added a sub-title to help potential readers understand the time frame of his study: State of the Russian Empire and Grand Duchy of Muscovy with that which has happened there most memorable and tragic during the reign of four emperors: that is to say, from the year 1590 up to September 1606. When the second edition of Margeret's book was being prepared for publication in 1668 , its editors were unable to find much information about the author. As a result, in writing about Margeret they took their cue from the dates listed in the sub-title of his book. Since Margeret's book covered the period from 1590 to 1606 , it was not illogical to assume that he was already in Russia by the early 1590s. The editors decided that Margeret must have departed for Russia "around 1591." That faulty conclusion in 1668 was accepted without question by the aspiring Margeret brothers in $1699^{10}$ [8, p. 458-459].

In preparing the dossier to support their bid to become hereditary sword nobles, the Margeret brothers made many mistakes, and they embellished their family history to claim more soldiers and fewer merchants as ancestors. They 
also purged Huguenots from their lineage - a necessity after Louis XIV revoked the Edict of Nantes in 1685. The rather famous Captain Margeret who wrote Estat de l'Empire de Russie was only a distant relative of the Margeret brothers, but they turned him into one of their direct ancestors. This sleight of hand was facilitated by an erroneous statement made in 1668 by their ancestor Pierre Margeret, grand audiencier of Louis XIV. Pierre claimed to be Captain Margeret's great nephew, but Jacques was actually a cousin of Pierre's grandfather [8, p. 448449, 456-458; 80, p. 465-466]. Ignoring ample evidence that Captain Margeret's forename was Jacques, the Margeret brothers declared that his name was Étienne. They managed to convince French officials that they were worthy of promotion, but Berelowitch failed to make a persuasive case for Captain Margeret and Étienne Margeret being the same person [8, p. 448, 456459]. At the dawn of the eighteenth century the Margeret family's dream of rising from the bourgeoisie into the sword nobility finally came true. Unfortunately, the sloppy and misleading paperwork associated with their success confused some future scholars.

Jacques Margeret entered Russian service in 1600. Tsar Boris Godunov (r. 1598-1605) was favorably impressed by the French captain and gave him command of a cavalry company. An intelligent, sober, and valiant soldier, Margeret served Tsar Boris with zeal for several years, rising to share overall command of the tsar's foreign troops which numbered several thousand $[4$, p. $28 ; 18$, p. $112 ; 46$, p. $169 ; 81$, p. $118 ; 116$, p. $605 ; 130$, p. 257] ${ }^{11}$. Captain Margeret's career in Russian service provides a good example of the "second wave" of foreign mercenaries in the era of the gunpowder revolution: European officers and soldiers who not only fought for the ruler who hired them but also helped train and organize native troops [107, p. 236-237]. Margeret's initial salary was high; he was paid 80 rubles per year in cash and received a service land grant (pomest'e) of 700 chetverti (about 4 square kilometers) [83, prilozh. no. 4, p. 266$273 ; 118$, p. 3; 130, p. 248-249]. Although Margeret spoke German to the tsar's foreign troops, he learned to read and to communicate effectively in Russian [4, p. 30; 48, p. 9; 55, p. 21; 67 , p. 426 ; 78 , p. xviii; 80 , p. $22-23$; 81, p. 83 , 117;
$128 ; 130$, p. 245, 249]. While in Godunov's service, Margeret had the opportunity to observe many activities at court, in the tsar's bureaucracy, and in the field. When in Moscow, he lived close to the Kremlin; but his military duties took him to many parts of Russia, including the southern steppe frontier. Margeret's description of Russia's zasechnaia cherta (or zaseka) defense lines and the early warning system set up to oppose Tatar invasions provides invaluable evidence unique among foreign accounts of early modern Russia $[46$, p. $174-177 ; 73$, p. $43-45 ; 74$, p. $15 ; 85$, p. $482-$ 483; 129, p. 54-64].

Captain Margeret was in the tsar's army sent to repel the pretender Dmitrii Ivanovich's invasion in 1604-1605. Margeret's actions at the battle of Dobrynichi (January 1605) were instrumental in the defeat of Dmitrii's army, for which he received special thanks from Tsar Boris. Margeret was silent about his own actions during the battle and credited the Russian infantry for the victory. Nevertheless, eyewitnesses and Tsar Boris were certain that it was Captain Margeret's own daring and tactical brilliance that won the day $[4$, p. 17,$33 ; 18$, p. $102 ; 19$, p. $40-41 ; 73$, p. $62-63 ; 82$, p. $86-89 ; 81$, p. $82-84 ; 123$, vol. 1 , p. $237 ; 127$, p. $165 ; 130$, p. $250,255,273-276]$. At the outset of the battle, Dmitrii's Polish cavalry launched such a ferocious attack against the main force of the tsar's army that it wavered and began to retreat in disorder. Dmitrii's cavalry pressed the attack and captured some artillery. Seeing the danger, Captain Margeret led the foreign troops forward from the flank of the tsar's army. The Dutch merchant Isaac Massa described the scene: "[The] Germans and the Livonians in Boris's service, commanded by a Frenchman, Captain Jacques Margeret, pulled together, placed themselves at the head of the army in the face of the enemy, and began skirmishing with them" [81, p. 83].

In the words of Conrad Bussow, a soldier who was an eyewitness [19, p. 40]:

“[Margeret's men] attacked Dmitrii's formations with such force that not only were they unable to pursue the fleeing Muscovites but they were even forced to abandon the captured artillery and flee headlong. The German battle cry was 'Hilff Gott! Hilff Gott!' God helped them. They boldly pursued Dmitrii's fleeing army, fired at the horsemen, and cut down all those they could reach or pursue. When the 
Muscovites saw the bravery of the Germans, and how they alone were driving the enemy from the field and pushing them back, they regained courage and came in thousands to the aid of the Germans, learning also to call out the German battle cry 'Hilff Gutt!' Hilff Gutt!' and the Germans were not a little amused [to see the Muscovites] appropriate the German language and battle cry so well."

Tsar Boris's Russian soldiers strongly praised the foreign mercenaries for their valor, and Captain Margeret's bravery and the German battle cry were immortalized in Pushkin's Boris Godunov ${ }^{12}[19$, p. $40 ; 30$, p. 66-67, 71, 100, 102, 107, 151-152, 201-202, 406-409, 495, notes 201-202].

The tactic used next by the Russian infantry at Dobrynichi that Captain Margeret commended had never before been seen in Russia. Foreign officers had trained and organized the Russian infantry to fight in a linear formation, utilizing new Dutch tactics for the delivery of mass firepower in battle [19, p. 40; 46, p. 164-165; 95, p. 231-232; 107, p. 237-238]. Margeret wrote that while the armies were skirmishing, Dmitrii "played for double or nothing" in a bold attempt to regain the initiative. According to Margeret, "Dmitrii sent his main cavalry along a small valley to attempt to cut between the village and the Russian army" [73, p. 63]. But Captain Margeret and other officers had anticipated such an attack and deployed the strel 'tsy in a long line, some of them behind prefabricated wooden barricades [81, p. $84 ; 107$, p. 236-238]. Margeret described what happened next: "The [tsar's] infantry, seeing the Poles so near, fired a volley from ten or twelve thousand harquebuses which so frightened the Poles that they turned back in great confusion" [73, p. 63]. Simultaneously, approximately three hundred cannon were fired at Dmitrii's attacking cavalry, killing many men and horses and adding to the incredibly disorienting noise and smoke. Captain Margeret himself was almost certainly responsible for this new, highly effective battle formation - a Russian variant on the Dutch model [36, p. 220, note 188; 46, p. 162-168; 73, p. xviii, 98, note 36; 81, p. 84]. That should not be too surprising since Jacques's cousin, Captain Claude Margeret, worked for Prince Maurice of Nassau, a principal inventor of the new tactics for enhancing infantry mass firepower [9, p. 312; 94].
Captain Margeret returned to Moscow after the battle of Dobrynichi to receive the tsar's thanks and to participate in a victory parade. Tsar Boris generously rewarded Margeret and his men, who received a year's pay in advance. Margeret was almost certainly allowed to exchange some of his service land grants for high-status votchina estates $[18$, p. $102 ; 19$, p. $42 ; 46$, p. 51, 56-57; 116 , p. $605 ; 123$, vol. 1, p. 237; 130, p. 248]. Soon after Tsar Boris died in April 1605, the tsar's army submitted to the pretender Dmitrii. To their credit, the foreign mercenaries remained loyal to Tsar Fedor Borisovich (r. 1605). But when the citizens of Moscow overthrew the Godunov dynasty and welcomed Tsar Dmitrii (r. 1605-1606), the foreign troops had little choice but to join the Russians in recognizing Dmitrii as tsar. On June 20, 1605, Margeret and his officers met with Tsar Dmitrii at his camp in Kolomenskoe. They begged the new tsar not to be angry with them for their actions at the battle of Dobrynichi. Tsar Dmitrii smiled and commended them for their skill, valor, and steadfastness to the oath they swore to Tsar Fedor. Dmitrii promised them that if they displayed the same zeal for him, he would rely on them more than his Russian army. In this way, Captain Margeret entered Tsar Dmitrii's service and retained his position as commander of the tsar's foreign troops $[18$, p. $102 ; 19$, p. $49 ; 67$, p. 425 ; 73 , p. xviii; 81 , p. $117 ; 82$, p. $86-89$; 130 , p. $250-$ 251]. Tsar Dmitrii was impressed by Captain Margeret, and the feeling was mutual. Perhaps because Dmitrii's career reminded him of Henri IV's rise to power, Margeret was quite willing to serve the new tsar.

During his campaign for the throne, Dmitrii had observed the weaknesses of the Russian army, and he knew it needed modernization. Tsar Dmitrii sharpened the martial skills of his Russian troops by requiring them to receive active field training, especially in siege warfare. According to Isaac Massa, the tsar personally "took part in these exercises as a common soldier, and spared nothing to instruct the Muscovites in the science of war" [36, p. 220;81, p. 117]. Historians traditionally believed that modern military tactics arrived in Russia during the reign of Tsar Vasilii Shuiskii (r. 1606-1610), but Soviet military historians correctly discerned that modernization began earlier, during the reign of Tsar Dmitrii. Since Dmitrii often used his foreign troops to train 
Russian soldiers, it is highly probable that Jacques Margeret helped modernize Russian infantry tactics and maneuvers $[4$, p. 17,$33 ; 11$, p. $61 ; 18$, p. $102,186-187 ; 19$, p. $44,55-56 ; 46$, p. $162-168$; 81 , p. $100,117-118 ; 82$, p. $86-89 ; 86 ; 106$, p. $67-$ 76; 130, p. 250-251, 255, 273-276]. In January 1606, Tsar Dmitrii created an elite bodyguard of 300 foreign mercenaries led by Captain Margeret, who personally commanded the first company of the guard composed of 100 "archers," mostly Germans and Livonians ${ }^{13}[18$, p. $112 ; 19$, p. 5354; 36, p. 215; 81, p. 116-118, 121; 123, vol. 1, p. $238 ; 130$, p. 250-257]. Despite the name, the tsar's archers carried partisans (pole-axes) with the tsar's coat-of-arms stamped in gold on the blades, and their weapons were covered in red velvet bound by silver wire. The archers wore strikingly beautiful uniforms of red velvet and cloth-of-gold, and they accompanied the tsar everywhere. When he left Moscow they accompanied him on horseback holding matchlock guns at-the-ready. Tsar Dmitrii's enemies later portrayed this as a "heretical innovation" that greatly upset the Russian lords [92, p. 112-113; 99 , p. 36-37; 130, p. 254]. That is an exaggeration. It is worth noting that the usurper Vasilii Shuiskii retained Dmitrii's "heretical" foreign bodyguard [73, p. xviii-xix, 78-79]. Tsar Dmitrii's archers received the highest pay in the Russian army [1, s. $18 ; 78$, p. ix; 81, p. 117; 82, p. 118; 123, vol. 1, p. $238 ; 130$, p. $251-255,257]$. Captain Margeret received an increase in salary and more land, including a village with a tavern. Margeret enjoyed many privileges, and the tsar had complete confidence in him $[3$, p. $409 ; 116$, p. $605 ; 123$, vol. 1, p. 238; 130, p. 238, 248, 254, 257].

In May 1606 Tsar Dmitrii was assassinated by a small group of disgruntled Russians led by Vasilii Shuiskii [36, p. 226-238]. Dmitrii had been repeatedly warned by Captain Margeret and others of a plot to kill him, but the tsar foolishly dismissed those warnings. On the night he was murdered, Tsar Dmitrii sent most of his bodyguards out of the Kremlin to protect his Polish wedding guests from hostile encounters with the city's agitated population. The tsar had only a few guards and no officer with him when Shuiskii struck [36, p. 231-232, 235; 60, p. 41-42; 81, p. 135, 137-138]. Captain Margeret was sick and not on duty that night. That probably saved his life and may even have been a factor in the conspirators' decision to strike when they did [21, vol. 14, p. 494; 104 , vol. 14 , p. 177] ${ }^{14}$. Over the years historians have credited propaganda and rumors about the involvement in the conspiracy of persons close to Dmitrii, including his "mother," the Romanovs, Prince Fedor Mstislavskii, and Captain Margeret $[36$, p. $232 ; 89$, p. $506 ; 101$, p. $82 ; 114$, p. $17-18$, 38,$42 ; 126$, p. 59-60]. The rumor that Margeret supported the conspiracy was put forward by a confused and frightened foreigner being held in custody and in no position to know anything about the assassination $[85$, p. $484 ; 87$, p. 76]. In fact, Margeret was devoted to Tsar Dmitrii, which is obvious to anyone who reads his book.

Before killing Tsar Dmitrii and seizing power, Vasilii Shuiskii tried to demonize Tsar Dmitrii's foreign troops in a whispering campaign against the impostor "Grishka Otrep'ev." Once in power, Tsar Vasilii felt compelled to dismiss most of the foreign mercenaries in the Russian army. Given no severance pay, many of them were reduced to begging and robbery by the time they reached the border. Shuiskii did try to retain key officers who wished to leave Russian service [21, vol. 14, p. $504 ; 36$, p. $271 ; 73$, p. xix-xxi; 81 , p. $153 ; 85$, p. 484]. The new tsar asked Captain Margeret to remain as commander of his foreign bodyguard, which Margeret agreed to do. Tsar Vasilii's request was, of course, virtually a command, but the miserable plight of those foreign troops Shuiskii had dismissed may also have influenced Margeret's decision to remain in Russia somewhat longer. Captain Margeret accompanied Shuiskii on several occasions when the new tsar came close to being attacked by the residents of Moscow. Many ordinary Russians regarded Shuiskii as a usurper who had murdered their beloved Tsar Dmitrii [36, p. 247-250; 73, p. 75$79 ; 85$, p. $485-486 ; 114$, p. 43, 49]. Margeret also detested Shuiskii and took the first available opportunity to leave Russian service in good standing. By mid-summer he managed to secure the tsar's reluctant permission to return to France. Tsar Vasilii gave Captain Margeret rich presents in recognition of his long and faithful service to Russia ${ }^{15}$ [85, p. 482-485; 130, p. 258-260]. Margeret departed for France from Arkhangel'sk in September 1606, probably sailing on an English ship. It has been claimed that Captain Margeret "abandoned" Russian service because he saw the whole country rising in mutiny against the usurper 
Shuiskii [78, p. xii; 82, p. 154; 130,p. 258]. That is simply not true. Margeret received permission to leave Russia at a time when Tsar Vasilii was still confident that his forces could easily overcome any rebellion. Margeret departed from Arkhangel'sk before news of the scope of the rebellion against Shuiskii could reach him [69, p. 41(v)-42, 45(v)-46, 47-47(v); 73, p. 75-80]. By the time he arrived in France, however, Moscow was under siege by tens of thousands of rebels determined to restore "Tsar Dmitrii" to his throne.

Soon after returning to France, Captain Margeret presented himself to King Henri IV. Margeret gave the king a sample of Tsar Dmitrii's diplomatic correspondence and a petition from Bertrand of Kazan, a business associate of Jacques' father who had been living in Russia for many years and lost his fortune when Tsar Dmitrii was assassinated. Henri later wrote to Tsar Vasilii on Bertrand's behalf [23, p. 444-445; 39, p. 330331]. King Henri listened with pleasure to Jacques's stories about Russia and ordered him to write a book about that mysterious land [69, p. Aiii; 70, p. aii-aii(v); 130, p. 260]. Henri was keenly interested in Russia, especially the meteoric career of Tsar Dmitrii. Russia was also of considerable interest to Jacques-Auguste de Thou, the royal librarian and foremost historian of the age. De Thou interviewed Margeret at length and included much of the French captain's information about Russia in his own monumental Historia sui temporis. It is likely that de Thou urged the king to commission Margeret's book in order to correct many popular and scholarly views of Russia then current in Europe. Nevertheless, Henri IV deserves much of the credit for the appearance of Margeret's book. Without the king's great curiosity, the restless Captain Margeret might never have published his brilliant account of Russia [21, vol. 14, p. 450-467, 490-504; 73, p. xxvii-xxx; 78, p. xvii-xviii; 80, p. 420-423; 104, vol. 14, p. 125-131, 157-163].

Jacques worked on Estat de l'Empire de Russie during winter 1606-1607, and he published it in March 1607. Margeret attempted to write an objective account of Russia following the guidelines laid down by the great French Renaissance scholar Jean Bodin and the Ancients (primarily Polybius). Captain Margeret fit Bodin's description of a most reliable historian: an open- minded person who spent a great part of his life holding important offices and in warfare, a man of experience who did not praise himself in his writings but who attempted instead to present an account devoid of emotion and partisanship. Margeret sought to speak only the truth about Russia, unadorned by "heroics" or literary flourishes, so that the French reading public might discern the truth in his words and learn from it [7, p. $35-37$; 9 , p. $313,320-321 ; 12$, p. xxxvii, 41-44, 50-51; 69, p. Aii-Aiii; 73, p. 3-4]. Although Margeret's writing style is somewhat unpolished and simpler than that of the great writers, it is straightforward, vigorous, and typical of the late French Renaissance. Margeret was not a professional writer, but his prodigious knowledge of Russia, combined with his intelligence, honesty, keenness of observation, and careful differentiation between fact and opinion, made his account a work of lasting value $[1$, s. $45 ; 70$, p. aiiaiii; 73, p. xxx; 78, p. 3-7; 99, p. 37; 123, vol. 1, p. $241 ; 130$, p. 245]. As soon as it was published, Margeret's book became influential in shaping French and European views of Russia, and it has been used extensively by scholars ever since. Margeret's account of Russia has long been regarded as an extremely valuable and highly accurate source for reconstructing the early history of the Time of Troubles $[4$, p. 14, 20, 29; 18 , p. 32-34; 19, p. xxxi; 63, p. 104, 411, 413, 418; 73 , p. 8, 20-21; 85, p. 480-481].

Scholars have long been puzzled by Margeret's ability to write his book so quickly. One clue to the mystery may be found in Margeret's writing style. His narrative has an informal, oral tone to it, as if one were listening to the unpretentious soldier's own voice. That stylistic feature is due at least in part to how the book was produced. Margeret almost certainly dictated his account to a court scribe ${ }^{16}$. To explain how Margeret managed to write such an accurate account of Russia so quickly, scholars have reasonably suggested that he must have taken extensive notes while in Russian service and may even have worked on a rough draft of his book while living in Russia or on his journey back home to France ${ }^{17}$ [80, p. 16]. Expanding on the work of Iurii Limonov, Dmitrii Liseitsev carefully studied Margeret's remarkably accurate information about the tsar's bureaucracy. Liseitsev attempted to identify Margeret's expert informants and made a 
good case for officials in the Posol'skii prikaz, including Afanasii Vlas'ev. Liseitsev claimed that the accuracy of Margeret's information about the tsar's prikazy implies that Margeret relied not just on expert informants and his own observations, but that he also consulted written Russian sources in preparing his account for publication. That is undoubtedly true; there is even evidence that Margeret read some Russian chronicles [4, p. 30; 61, p. 221-222; 63, p. 93-95, 100-103, 575; 73, p. 14 , 89,109 , note 20,192 , note $353 ; 85$, p. $479-481$, 489-492].

Dmitrii Liseitsev claimed that Margeret made use of Giles Fletcher's controversial of the Russe Commonwealth (1591) in preparing his book. Liseitsev suggested that John Merrick may have given Margeret a copy of Fletcher's book in September 1606, but he provided no evidence to support such a dubious assertion. Liseitsev based his claim only on the similarity of some information about Russian administration found in Of the Russe Commonwealth and Margeret's book [63, p. 104]. In fact, there is no reason to believe Margeret ever saw Fletcher's book; he certainly did not need Fletcher's help to describe tsarist Russia or its administrative institutions. And why would the chief agent of the Muscovy Company recommend a book that his company successfully lobbied Queen Elizabeth I to suppress in 1591? Captain Margeret's positive description of Russia as a well-run absolute monarchy that practiced religious toleration was based on his own experience, and it has little in common with Fletcher's distorted description of the Russian government as "plaine tyrannical" [10, p. 150-154; 41, p. $20 ; 117$, p. 189-198]. Margeret did not need to consult Fletcher's book to be able to write knowledgeably about Russia, nor did he need to borrow information from earlier accounts of Russia. Instead, Margeret recorded only what he personally saw, heard, and read during six years of service as a high-ranking official in the tsar's government ${ }^{18}$.

Jacques presented King Henri with a copy of his book in spring 1607, and it was placed in the Royal Library ${ }^{19}$. Margeret then returned to Auxonne and Burgundy to visit his family and to manage his affairs. In Dijon Jacques made a formal claim to part of his grandfather Pierre's estate, in the process referring to himself as "escuyer" [modern French: écuyer] or "knight," meaning a nobleman $[9$, p. $315 ; 71$, pp. iii-iv, viii; 98, p. 193-194]. Some historians incorrectly assumed that the Margeret family was already noble by the time Jacques was born [24, p. 365; 89, p. 505]. That is not true. The Margerets were definitely bourgeois in the sixteenth century. Selfpromotion of soldiers into the ranks of the petty nobility was not uncommon in early modern France, but Jacques never again referred to himself as a "knight." Until the end of his career he was content to be addressed as "Captain Margeret."

In the years following Tsar Dmitrii's death, rumors persisted throughout Europe that he had somehow miraculously escaped assassination in 1606. Captain Margeret was undoubtedly interested in those rumors. He had never been completely convinced of Dmitrii's death because he was not an eyewitness, and at some point he decided to find out for himself if the rumors were true. By 1609 Margeret returned to Russia to fight against the usurper-tsar Shuiskii in the name of "Tsar Dmitrii." As soon as he arrived in Tushino, however, he discovered that the second pretender Dmitrii Ivanovich was an obvious impostor, merely a convenient tool of the forces gathered in opposition to Tsar Vasilii. Real power in Tushino rested in the hands of several Polish-Lithuanian lords and a few Muscovite dignitaries well known to Margeret, including the boyar Mikhail Saltykov. With no illusions about the identity of the second pretender, Margeret remained in Tushinite service. No doubt he was a welcome addition, as much for the propaganda value of having the captain of Tsar Dmitrii's bodyguard in camp as for his military skills. Margeret almost certainly received a generous land grant from the second pretender $[57$, p. $326-327 ; 69$, p. $41(\mathrm{v})-42,45-47(\mathrm{v}) ; 73$, p. $75-77 ; 130$, p. 262-263]. In 1612 Prince Dmitrii Pozharskii, senior commander of the Russian national liberation forces fighting against Polish intervention, accused Captain Margeret of being an "enemy" of Russia in part for having worked with the controversial cossack commander Ivan Zarutskii while in the second pretender's service [116, p. 605]. V.D. Nazarov claimed that Margeret never traveled to Tushino and never entered the second pretender's service. Nazarov rejected Pozharskii's accusation as nothing more than propaganda intended to make Margeret (and foreign mercenaries generally) look odious [85, 
p. 493]. That is not true. According to one of Margeret's close associates, he recruited foreign mercenaries for Tushinite service $[80$, p. $301 ; 110$, p. 18-23, 138-144].

When the second pretender Dmitrii's camp broke up at the end of 1609, Margeret and other Tushinite dignitaries were faced with the unenviable choice of either submitting to the hated Tsar Vasilii or entering into negotiations with King Sigismund III of Poland-Lithuania, whose forces were then invading Russia. Not surprisingly, the Tushinites chose to negotiate with the Poles and offered to support King Sigismund's son Władysław as tsar once Shuiskii was overthrown. Sigismund treated the Tushinite dignitaries as honored allies and promised that, as tsar, his son would protect the Russian Orthodox Church and use the Tushinite lords as a directing staff for Russian affairs. Sigismund also promised them vast estates. In negotiations with the Poles, the Tushinite lords insisted on retaining serfdom (no right of peasant departure) and enforceable measures to prevent greedy favorites of Tsar Władysław from poaching their peasants. All those demands were met by King Sigismund and are clearly reflected in the grants given to Captain Margeret [36, p. 406; 114, p. 83]. It is almost certain, therefore, that Margeret joined Polish service in February 1610 along with dignitaries such as Mikhail Saltykov ${ }^{20}$. When the Polish government finally issued land grants to the former Tushinite lords, Captain Margeret received two votchina estates and one pomest'e estate at about the same time Mikhail Saltykov and his son Ivan M. Saltykov received theirs 21 [3, p. 408-409]. Margeret's votchina grants unambiguously outlawed vykhod and vyvoz. The status Captain Margeret enjoyed at this time was higher than that of most other military officers. The larger votchina estate assigned to him by Sigismund III was over 1000 square kilometers in size, larger than most Russian nobles ever dreamed of possessing. The powers granted to Margeret to retain his peasants were unprecedented, and they have drawn comments from scholars. No one, not even the Patriarch of the Russian Orthodox Church (let alone a mere boyar) was permitted to poach Captain Margeret's peasants ${ }^{22}$ [3, p. 409-410].

Jacques Margeret entered Polish service in 1610 with the consistent goal of ousting the usurper Shuiskii [73, p. xix-xx; 99, p. 61]. If he is criticized for choosing to support Prince Władysław, that same criticism should apply to Filaret Romanov. Sometime after the Tushinite lords declared their support for King Sigismund's son as tsar, Margeret joined the Polish army that invaded Russia to topple Tsar Vasilii and put Prince Władysław on the tsarist throne. It is likely that Captain Margeret accompanied Ivan Saltykov's forces that joined up with the Polish army not long before the battle of Klushino in June 1610. The commander of the Polish army, Hetman Stanisław Żółkiewski, immediately put Margeret to work as a lieutenant of another former Tushinite officer, Pan Piotr Borkowski, who commanded the foreign mercenaries in the Polish army [78, p. xiv; 114, p. 86; 130, p. 263-265]. Margeret soon distinguished himself in Polish service.

Hetman Żółkiewski's army of 7,000 men was on a collision course with a Russian-Swedish army of 30,000 men commanded by the Swedish general Jacob De la Gardie. Żółkiewski tried to even the odds by prying loose disgruntled mercenaries in Tsar Vasilii's army. French deserters told the Polish general about the low morale of the tsar's foreign troops (who had not been paid in six months) and about the possibility of additional defections by their comrades. Żółkiewski sent Pan Borkowski and Captain Margeret to negotiate quietly with middle-ranking commanders of foreign troops in the tsar's army. Those officers were offered generous terms of surrender, including safe passage to leave the country or employment in the Polish army. Borkowski and Margeret were spectacularly successful, contributing directly to the defection of nearly 3,000 French, English, Scottish, and German mercenaries during the battle of Klushino, leading to a decisive Polish victory [43, p. 68-69; 47, p. 143-144; 71, p. viii-ix; 85 , p. 493; 114, p. 87$88 ; 116$, p. $605 ; 119$, p. $117-118 ; 123$, vol. 2 , p. 46$47 ; 125$, p. $127-128 ; 130$, p. $264,266-267 ; 131$, p. 75-81]. Possibly due to Margeret's skilful diplomacy, the first to defect were 600 French cavalrymen [19, p. 134-135, 201, note $98 ; 104$, vol. 14, p. 220-222]. The battle of Klushino opened the path to Moscow for Żółkiewski's army and doomed Tsar Vasilii. For the final assault on Moscow, Mikhail Saltykov was given command of 2,000 mercenaries who had surrendered at Klushino and chose to enter Polish service. It is 
likely that Saltykov asked Margeret to command a cohort of those foreign troops [116, p. 606; 123, vol. 2, p. 46-47; 130, p. 267].

By the time Żółkiewski's army reached Moscow, the boyars had already deposed the unpopular Tsar Vasilii. No doubt influenced by the presence of the Polish army, the boyars pledged support for Prince Władysław on the condition that he convert to Russian Orthodox Christianity. That decision was unpopular throughout Russia and led to unrest in Moscow. Many ordinary Russians considered the boyars in the governing "council of seven" (including Mikhail Saltykov) to be traitors. As unrest grew, the "council of seven" became so fearful of their own people that they took the drastic step of inviting Żółkiewski's army into Moscow to help restore order. At that point Żółkiewski thinned out his forces by dismissing most of the mercenaries who had joined his army after the battle of Klushino, paying them off with money withdrawn from the tsar's dwindling treasury [36, p. 409-413;88, p. $103 ; 130$, p. 268-269]. That left approximately 7,000 soldiers to garrison Moscow and protect the pro-Władysław "council of seven" and its supporters. To strengthen the garrison, Żółkiewski created an elite brigade of 950 of his best foreign troops under the command of Piotr Borkowski and his lieutenant, Jacques Margeret. Pan Borkowski led the 150-man cavalry company, and Captain Margeret led the 800-man infantry regiment [123, vol. 2, p. 46-47; 130, p. 269, 271]. Before Żółkiewski returned to Poland, he installed Aleksander Gosiewski as the military governor of Moscow. Gosiewski worked closely with the "council of seven," especially Mikhail Saltykov. To maintain order in Moscow, Captain Margeret also worked closely with Saltykov. As unrest grew, Gosieski imposed a harsh "military dictatorship" on the capital. Saltykov, the most visible boyar and Gosiewski's chief collaborator, soon became a more hated figure than the Polish general [36, p. 413, 417-420; 114, p. 106; 130, p. 268-270, 283-289].

The Moscow garrison was unpopular and suffered from low morale. The soldiers were not paid for many months, received inadequate provisions, and grew increasingly hungry [19, p. $166-167 ; 119$, p. 122, 125]. As their frustration and anger grew, soldiers in the Moscow garrison contacted soldiers in Polish occupation forces elsewhere in Russia. Many of them were also suffering and on the verge of quitting. In early 1611 , a delegation of soldiers traveled from Moscow and elsewhere to Sigismund III's siege camp near Smolensk to demand back pay from the king. Fed up with delays and excuses, soldiers of the Moscow garrison warned Sigismund's advisors that if they did not receive the money they were owed by April 1611, they would abandon Moscow or elevate to the tsar's throne whichever boyar was willing to pay them [68, s. 84-85]. King Sigismund was financially embarrassed at that time and unable to pay his soldiers. He solved his problem by authorizing the withdrawal from the tsar's treasury of funds and precious objects to be given as salary to his unpaid soldiers. Sigismund's instructions specified the sums to be paid, and the king insisted on strict accounting and proper paperwork [16, p. 459]. The shock of being confronted by disgruntled soldiers may have convinced King Sigismund's staff to speed up delivery of the generous land grants promised to members of the "council of seven" and Captain Margeret. Those long-awaited grants were awarded in April and May 1611 [3, p. 403-411].

Prince Pozharskii claimed that Captain Margeret "shed Christian [i.e., Russian] blood" while in Polish service [116, p. 605-606]. There is no denying it. In fact, Margeret's bravery, cunning, and relentless assaults on insurgent positions were largely responsible for suppressing the March 1611 Moscow uprising. In the months leading up to that insurrection, several disparate groups gathered together to oppose the pro-Władysław government in Moscow. News of the approach of those patriot forces stirred the capital's population into action. By February 1611 Mikhail Saltykov and the "council of seven" were denounced almost daily by large crowds who barricaded the streets and occasionally rioted. Gosiewski ordered strel 'tsy units to disperse the crowds, and he concentrated his troops and ordnance in the inner city and Kremlin. Uncoordinated assaults on the Kremlin were easily driven off by elite harquebusiers under the command of Captain Margeret [5, s. $408 ; 36$, p. $414-418 ; 114$, p. $121-126 ; 130$, p. 270-272].

In early March 1611 Pozharskii's insurgent forces approached Moscow and began to infiltrate 
the city. On March 19, a major effort was made to liberate the capital from the hated Poles. An initial encounter between cavalry from the Moscow garrison and insurgents in Kitaigorod led to severe Russian losses followed by an impetuous Polish advance into Belyi Gorod. There the Poles encountered stiff resistance from barricaded Muscovites reinforced by Pozharskii's soldiers with harquebuses. The insurgents drove the Polish cavalry back into Kitaigorod, pressing them so hard they were forced to retreat all the way to the Kremlin wall.

Conrad Bussow, an eyewitness, described the scene [19, p. 161-162]:

"If there had not been in the fortress a regiment of musketeers hired from among the Germans and other nationalities, and also the Poles, not one of the five thousand lancers would have been left alive on that day... When the Poles had been so ingloriously repulsed by bullets and arrows back to the gates of the fortress, and had been seized by great fear, the captain of the foreign troops, Jacques Margeret, at the eighth hour, according to our reckoning, sent out into Nikitsk street three companies of musketeers, altogether numbering about four hundred men. This street, which is about a quarter mile long, had many intersections, where about seven thousand Muscovites were crouching behind the barricades or in the trenches and inflicting heavy losses on the Poles. The four hundred musketeers, in the name of the Lord, attacked the [Russians] behind the first barricade, and their volley was so effective that the Muscovites fell like sparrows before buckshot. ... The soldiers set about them with their rapiers as fiercely as dogs, ... [and] returned looking like butcher's apprentices. Their rapiers, hands, and clothes were covered in blood, and they were a gruesome sight. They had destroyed many Muscovites but had lost only eight of their own soldiers."

The martial skill and bold tactics of Margeret's harquebusiers inflicted thousands of casualties and inspired the Poles to launch a counterattack that drove the insurgents almost completely out of Kitaigorod [89, p. 507; 123, vol. 1, p. 238240; 130, p. 275-276; 131, p. 123-124].

During the early morning hours of March 20, Pozharskii's forces again approached the Kremlin and began to fortify their advanced positions in preparation for a frontal attack. Significant forces were also stationed along the wall between Kitaigord and Belyi-gorod to shoot at the Poles and support the planned assault.
Once again, Conrad Bussow described the scene [19, p. 162-164]:

"But Captain Jacques Margeret employed a fine stratagem. He let them complete their redoubt and guard it. Since the ice on the Moskva was still firm enough, he led his men out through the water-gates of the fortress onto the river and so, could attack to left and right at will. ... Captain Jacques Margeret proceeded along the ice with his soldiers, along the White Wall as far as the fifth tower, and then skirted the city and re-entered the city gates, being at the rear of the enemy, who had not expected any danger from that quarter and had kept the gates open for their friends who were behind other barricades or in the redoubts. Thanks to this the Russians lost, since they were defending the forward redoubts more strongly than the gates in their rear. Unexpectedly for them, in an instant our men attacked the redoubts and quickly came upon them, slaughtering all who were in them, setting fire to the redoubts ... our soldiers also went over to the other bank of the Moskva and there set fire to the redoubts and all the houses they could reach. No war cries or bells could help the Muscovites. Our soldiers were aided by wind and fire, for wherever the Muscovites fled they were followed by wind and the flames ... Towards midday there was not the slightest resistance; neither were any Muscovite soldiers anywhere to be seen. So, in the course of two days the great metropolis of Moscow, having a circumference of more than four German miles, was reduced to dung and ashes, and nothing remained except the imperial fortress and its suburb, which were occupied by the king's men, and some stone churches."

Between 7,000 and 10,000 insurgents were killed during the uprising. Prince Pozharskii was seriously wounded and forced to retreat, delaying the liberation of Moscow for another year and a half. That undoubtedly influenced the extremely negative views of Captain Margeret found in Pozharskii's correspondence during 1612-1613 [68, s. $87 ; 116$, p. $605-606 ; 130$, p. 276-280]. Not surprisingly, some Russian and Soviet historians blamed Margeret for the fire that destroyed much of Moscow [123, vol. 1, p. 238; 130, p. 280]. Although he played a decisive role in the battle, there is no evidence that Margeret made the decision to burn the outer city. Sources on the subject are contradictory. Some place responsibility for the conflagration on ordinary soldiers setting fire to enemy positions during the battle. Other sources claim that Gosiewski made the decision to burn the city or that Mikhail 
Saltykov and the "council of seven" instigated it at the request of rich merchants who feared the consequences of an insurgent victory $[19$, p. 164; 36, p. 418-420; 130, p. 276-280; 131, p. 123-124].

Captain Margeret remained in smoldering Moscow with the beleaguered Polish garrison for another six months. He and Borkowski made occasional forays to keep roads in the area open, and in August they linked up with and escorted Polish troops bringing much-needed food supplies to Moscow [130, p. 282]. By then, Margeret had concluded that the fiction of "Tsar Władysław" was just a cover for the brutal conquest of Russia by Sigismund III. Margeret was well aware that Patriarch Germogen had urged all Russian Orthodox Christians to resist the Polish conquest of their country or face the prospect of being forced to convert to Roman Catholicism. At some point, Huguenot Margeret decided to oppose the conquest of Russia by Catholic Poland's "Jesuitking." In late 1611 some Protestant soldiers deserted the Moscow garrison and offered their services to the Russians [80, p. 292; 130, p. 291292]. Margeret chose a different path but with a similar goal in mind.

Prince Pozharskii accused Captain Margeret of robbing the tsar's treasury while he was in Polish service [80, p. 283; 111, col. 326; 114 , p. $155-156,170 ; 116$, p. $605-606 ; 130$, p. $282-$ 290]. The accusation is unfair, but it is understandable. Kremlin records include documents showing that Margeret frequently withdrew precious objects from the tsar's treasury from September 1610 to August 1611 [80, p. 265 273; 111, col. 232-236, 241-245, 251-253]. Contrary to the conclusions of some historians, however, those documents were not composed by angry Russians tabulating the theft of the tsar's treasure. Instead, they were written during the period of Polish occupation by scribes following King Sigismund's orders to keep detailed and accurate records of all payments made to soldiers in the Moscow garrison. Because Margeret served as paymaster for his elite infantry regiment, he made periodic withdrawals from the tsar's treasury to pay the salaries of 800 elite harquebusiers as well as his own salary [9, p. 319; 16 , p. $459 ; 80$, p. $265-270,273,340$, note $2 ; 130$, p. 268-269, 283-289; 131, p. 102]. As instructed, Margeret carefully recorded all his withdrawals and signed for them. Margeret's elite harquebusiers received high salaries (approximately 40 rubles), but they were not paid in cash. Instead, they were paid in valuables and precious objects taken from the Kremlin treasury and Tsar Vasilii's properties [36, p. $413 ; 80$, p. $265-269$, 285, 289$290 ; 111$, col. 222-248; 130, p. 285]. The sight of hundreds of foreign mercenaries carrying off the tsar's treasure must have infuriated Russian patriots, but it was not robbery. Margeret's men were paid in precious objects simply because there was no ready money left in the tsar's coffers by the time Shuiskii was deposed, and Żółkiewski took much of the remaining gold with him when he returned to Poland-Lithuania [80, p. 265-266; 81 , p. $168 ; 88$, p. $103 ; 119$, p. $95-96$; 130, p. $268-$ 269, 283-284]. The Kremlin treasury still contained many precious objects such as gold cups and a great many pearls $[68$, s. 85]. Soldiers in the Moscow garrison were not pleased to be paid with precious objects instead of money. Frustrated and bored foreign troops not infrequently used pearls as ammunition and fired them randomly at ordinary Muscovites going about their business [19, p. 166]. In a real insult to the Russians, someone cut Ivan the Terrible's "unicorn-horn" imperial staff into small pieces and gave them to the mercenaries as part of their salary. Decades later, the Russians were still complaining about the loss of the tsar's precious unicorn-horn staff ${ }^{23}[73$, p. 37,133 , note $115 ; 80$, p. $290 ; 91$, p. $190 ; 104$, vol. 14 , p. 117 ; 111, col. 235-236, 243].

Captain Margeret's annual salary (September 1610-August 1611) was 300 rubles, about half that of Pan Borkowski and about three times that of a Kremlin bureaucrat (d'iak). Margeret's Soviet biographer, Givi Zhordaniia, mistakenly claimed that he took precious objects from the Kremlin treasury worth 1800 rubles as his salary. Zhordaniia failed to notice that the figure 1800 rubles included expensive gold objects taken not by Margeret but by boyar Fedor Sheremetev [80, p. 265-273, 289-290; 111, col. 232-236, 243; 130 , p. $283-284,289-290]$. As a member of the "council of seven," Sheremetev was responsible for sending precious objects and expensive furs to King Sigismund. Most of what he withdrew from the treasury was destined for the king of Poland, not Captain Margeret. Nevertheless, the "council of seven" had been charged by Sigismund to distribute rewards to the heroic defenders of Moscow, and some of what Sheremetev withdrew 
may have been intended as a reward for his "товарыщ” Margeret. Kremlin treasury records clearly indicate that Margeret's salary of 300 rubles was paid with small gold crosses encrusted with precious stones. That was a practical choice; small crosses were easy to transport and sell. It is possible that Sheremetev also gave Margeret his reward for heroic service at this time. If so, that reward almost certainly consisted of loose pearls. Kremlin records show that Sheremetev and his “товарыщ” withdrew pearls valued at 986 rubles [80, p. 267-268; 111, col. 234-235; 114, p. 155156, 170]. Why would Captain Margeret choose pearls as his reward? His father probably taught him that they were a sound investment. Pearls were easy to carry and easy to sell, especially to Russians. Russian lords and ladies wore lots of pearls [73, p. 31, 37].

In October 1611 Captain Margeret and four hundred of his elite harquebusiers escorted Mikhail Saltykov and other boyars to Poland-Lithuania for a meeting with King Sigismund. Charges that Margeret once again "abandoned" Moscow, perceiving the hopelessness of the Polish position, are completely false. Margeret's correspondence in this period makes it clear that he actually feared Sigismund III would prevail in Russia [104, vol. 14, p. 225-226; 130, p. 283284, 293]. The charge that Margeret robbed the Kremlin treasury (again) on his way out of Moscow is also false. Saltykov ordered Margeret's harquebusiers to load a wagon with precious objects from the tsar's treasury to be delivered to King Sigismund as a gift [111, col. 326; 114, p. 170-171]. When the embassy arrived in Warsaw, Captain Margeret was warmly received by King Sigismund, who commended him for his heroic defense of the Moscow garrison. It is quite possible that Sigismund summoned Margeret from Moscow to seek his expert advice. The king appointed Captain Margeret to his royal council where plans for the conquest of Russia were being developed. Margeret learned that serious efforts to maintain the Moscow garrison were to be followed in 1612 by a major campaign to subdue Russia led by King Sigismund himself. Margeret had very different plans, however, and he soon found an excuse to resign from Sigismund's council ${ }^{24}$ [116, p. 606].
Margeret departed from Warsaw in late 1611 determined to do all he could to frustrate Sigismund III's plan to conquer Russia in 1612. Knowing that quick action was necessary, Margeret looked around for the best available opportunity open to him. His attention was immediately drawn to the court of the Elector of Brandenburg, Johann Sigismund (r. 1608-1619). There a former regimental commander in the elector's army, Baron Adrian Flodorf, was permitted to quietly launch a private venture to provide mercenary soldiers to Russian forces resisting Polish aggression. To avoid embarrassing the elector, Flodorf moved his base of operations out of Hohenzollern territory to the free imperial city of Hamburg [90, p. 110-113; 130, p. 291-292, 303-304, 309, 319-320]. In January 1612 Margeret joined Flodorf in Hamburg ${ }^{25}$, and they began recruiting soldiers for Russian service [130, p. 322]. Margeret wrote to the insurgent Russian government expressing his sincere desire to help them fight against Sigismund's planned invasion. He promised to provide them with soldiers by early Spring 1612 [49, p. 125-126; 80, p. 301]. Not surprisingly, Margeret did not receive an answer. Flodorf's efforts to raise troops for Russian service also ran into difficulties, including competition from Swedish recruiters and the hostility of the Dutch government [119, p. 125$126 ; 130$, p. 319, 322]. In late January 1612 Margeret wrote to John Merrick, chief agent of the Muscovy Company, expressing great concern about King Sigismund's planned invasion of Russia. He told Merrick that without foreign troops to help them, the Russians would almost certainly lose [104, vol. 14, p. 226].

In June 1612 Baron Flodorf and a company of ninety soldiers of various nationalities appeared in north Russia. They were received with honor and puzzlement by Arkhangel'sk authorities. When they approached the provisional government of Prince Dmitrii Pozharskii with an offer to help expel the Polish army from Russian soil, they were flatly turned down. Pozharskii feared that Flodorf and his men were scouts for some foreign power intent on seizing Arkhangel'sk just as the Russians were at last successfully reorganizing themselves and making plans to liberate Moscow. A major reason for rejecting Flodorf's offer was that, before the mercenaries arrived, Pozharskii had received a warning from the Swedish general 
Jacob De la Gardie that Flodorf's goal was to seize Arkhangel'sk. At about the same time Flodorf showed up, Pozharskii received another warning about a foreign threat to Arkhangel'sk, this time from a mysterious Frenchman named François Lesquaire who was linked to Dutch opponents of Flodorf's mission ${ }^{26}$ [116, p. 604-607; 130 , p. 329-330, 338-339, 345-350, 358-359]. Those two warnings might have been sufficient to cause Pozharskii to reject Flodorf's offer of assistance, but seeing Margeret's name listed as a colonel in Flodorf's letter to the Russians was simply too much for Pozharskii. Although his wounds from the failed attempt to liberate Moscow had healed, Pozharskii definitely continued to fear Margeret as an opponent. $\mathrm{He}$ was especially concerned about possible cooperation between Margeret and cossack commander Ivan Zarutskii that might disrupt Pozharskii's renewed effort to liberate Moscow. Pozharskii was utterly convinced that Margeret was an "evil" Catholic mercenary soldier determined to seize Arkhangel'sk for Sigismund III and the pope. Fearing the worst, Pozharskii ordered the reinforcement of Arkhangel'sk to stop Margeret from re-entering Russia and seizing that vital port. He also ordered the honorable detention of Flodorf and his men and an immediate investigation into their relationship to Captain Margeret [34, p. 208-210; 73, p. xxixxii; 99, p. 47-48; 116, p. 606; 123, vol. 1, p. 239$240 ; 124$, p. $253-254,282-284 ; 130$, p. $302-307$, 310, 316-317]. Some Russians criticized Pozharskii's denunciation of Margeret and regarded the Frenchman as an honorable soldier whose reputation had been unfairly ruined by Swedish propaganda $[38$, p. 364 , note 29,375 ; 66, p. 141].

Denied an opportunity to help the Russians liberate Moscow, Margeret looked for another way to frustrate King Sigismund's ambition to conquer Russia. In his January 1612 letter to John Merrick, Margeret expressed his intention to travel to England to consult with Merrick. Iurii Limonov has suggested that Margeret became an agent of Merrick and the Muscovy Company at this time [77, p. 14-16; 104, vol. 14, p. 226]. That is possible. Margeret had known John Merrick for over a decade, and his correspondence shows genuine concern for the fate of the Muscovy Company. In any case, Margeret knew that Merrick and his associates greatly feared the consequences of a Polish-dominated Russia, and he knew their concerns were shared by King James I (r. 16031625). James had provided Baron Flodorf with a passport to show the Russians, and Merrick actively helped Flodorf interact with officials in north Russia [34, p. 210-212]. James began seriously contemplating direct English intervention in Russia in 1612. During that summer Merrick held conversations with "principal and eminent" Russians concerning the possibility of James establishing a protectorate over north Russia [65, p. 249]. Merrick returned to England in late fall 1612 filled with enthusiasm for the project. Muscovy Company merchants seized the opportunity and became strong supporters of intervention in north Russia. During the winter of 1612-1613, James also received proposals from former military officers who emphasized the fabulous riches that would flow to the king if he established a protectorate over north Russia. Intervention also received strong endorsement from ardent Protestants such as the Archbishop of Canterbury who adamantly opposed Poland's attempt to capture Russia for the CounterReformation. Royal Navy officials expressed support for intervention in order to secure strategically important hemp cordage. In spite of some grumbling by members of his Privy Council, James made up his mind to pursue the project by lateApril 1613 [31, p. 291-294, 297-299; 34, p. 222].

At about the same time King James made up his mind to proceed with the protectorate scheme, he received a letter from Captain Margeret that strongly encouraged him to intervene in Russia and outlined "how to undo the intrigues and plots that the popes have always supported in order to set foot in Russia by means of the King of Poland". Margeret described the desirable traits a general should have to succeed in establishing an English protectorate over north Russia [32, p. 104-107; 80, p. 496]:

"Therefore, Sire, Your Majesty according to my judgment could begin the enterprise in this way: make a levy of some three thousand men and have them embark under the leadership of a general fit for such an enterprise - one who is wise, of good judgment, and who would have in mind the honour and the service of Your Majesty and not his own gain. Above all, he should not be obstinate but rather one who is prompt to seek advice and who can easily and quickly 
accommodate himself somewhat to the ways of the country. ... Also, Your Majesty, your army having entered the country will in case of necessity always be able to get help from His Lordship Prince Radziwiłł by land, and this at any hour needed without great expense."

Margeret's list of the desirable traits needed in a successful general sounds like a good selfdescription, and his letter has the feel of a job application. Depending on when James received Margeret's letter, the king of England may have been for a brief time a conscious rival of newlyelected Tsar Mikhail Romanov. In his letter Margeret mentioned Mikhail's election but urged James to proceed with intervention in part because many Russians resented the domination of the Zemskii Sobor by Cossack supporters of Mikhail Romanov. It is possible, therefore, that James and Merrick learned of Mikhail's election from Margeret's letter but wished to determine just how secure the new tsar was on his throne before abandoning the project altogether ${ }^{27}[31$, p. $297-$ 300; 32, p. 99-102, 105].

In spite of efforts to keep James's protectorate scheme a secret, by the time John Merrick arrived in north Russia in June 1613, the English project had been detected by the French, the Dutch, the Poles, the Swedes, and the Venetians. Russian authorities received several warnings about pending attacks on Arkhangel'sk by the English or other nations [31, p. 301-302; 34 , p. 225-226; 130, p. 299, 329-331, 353-355, 358367]. During the summer of 1613 Franzois Lesquaire reappeared in Russia and once again denounced Flodorf and his mercenaries for having designs on Arkhangel'sk. This time Lesquaire also claimed that the English intended to seize the rich Solovetskii monastery and were receiving aid from Sweden. Flodorf and the English merchants responded to those accusations by loudly denouncing Lesquaire as a liar and a Polish spy [2, p. 4-5; 37; 80, p. 10-11, 306-313, 316-319, 323, 325-326; 130, p. 332, 352-357]. During summer 1613 General De la Gardie also wrote again to the Russians accusing Flodorf of secretly planning to seize Arkhangel'sk. De la Gardie emphasized Flodorf's friendship with the "evil" Polish agent, Jacques Margeret [49, p. 127-128]. Nervous Russian authorities secretly interviewed the Dutch merchant Isaac Massa who warned them that the English were indeed planning to seize
Arkhangel'sk. Prince Pozharskii and newlyelected Tsar Mikhail reacted swiftly to these Swedish and Dutch provocations. Arkhangel'sk authorities were instructed to prepare for a naval assault with siege equipment directed by Captain Margeret [73, p. xxii, 98, note 34; 130, p. 359-367].

Russian authorities interrogated the English merchants about the Muscovy Company's connection to the evil Polish henchman Margeret. As a result, Merrick and his associates felt an urgent need to distance themselves from Margeret. In a diabolically clever move, they reworked information from various sources, including Pozharskii's 1612 decree denouncing Margeret, to fabricate a secret report to the Russian government about the arrival in Arkhangel'sk of Margeret's spies. According to the secret report, three Germans disguised as merchants brazenly displayed and tried to sell to the Russians precious objects that Margeret had stolen from the Kremlin treasury. The secret report urged Russian authorities to search for Margeret's (phantom) spies and to prepare for a siege by Russia's enemies. When asked to comment on the threat, John Merrick urged the Russians to fortify Arkhangel'sk before it was too late [80, p. 306-308, 316-319, 323, 325-326, 334$336 ; 130$, p. 330-331, 362-367]. The Russians did fortify the port, but they suspected Merrick was not being honest with them. They also suspected that Captain Margeret was somehow involved in the English plot even though they still believed him to be a bloodthirsty Catholic henchman of Sigismund III.

In one of his first acts of diplomacy, Tsar Mikhail (r. 1613-1645) sent ambassadors to England to announce his accession and to make discreet inquiries about possible ties between the Muscovy Company and the evil Captain Margeret who had killed many Russians, robbed the Kremlin treasury, and now plotted to seize Arkhangel'sk [49, p. $125-128 ; 80$, p. 495; 130, p. 313, 327-332]. The Russian ambassador's questions almost certainly made King James uncomfortable. Tsar Mikhail also sent ambassadors to France to warn King Louis XIII (r. 1610-1643) that Margeret was an enemy of Russia involved in a nefarious plot to seize Arkhangel'sk [130, p. 333-347, 355-357, 359-361]. Bitter memories of Captain Margeret also convinced Tsar Mikhail and his advisers not 
to hire any more French officers unless ironically - they were Huguenots [45, p. 169-170; 48, p. 10-11; 93, vol. 1, p. 429-434; 97, p. 30,354; 106, p. 169-175; 123, vol. 1, p. 180]. Despite Russian paranoia, Margeret was sincerely committed to stopping the Polish conquest of Russia. He was certainly not acting as a doubleagent for Sigismund III, as Zhordaniia suggested [130, p. 293-379]. Tsar Mikhail and Prince Pozharskii were wrong about Margeret's intentions, but who could blame them? By 1612 Margeret really did appear too compromised, and he undoubtedly suspected that he might no longer be welcome in Russia. That is probably why "Colonel Margeret" prudently remained behind in Hamburg waiting for a letter of reassurance from Flodorf that never arrived ${ }^{28}$ [90, p. 113].

What had Huguenot Jacques Margeret been doing since the failure of Flodorf's expedition? In his January 1612 letter to Merrick, Margeret mentioned that he hoped to return to France [104, vol. 14, p. 226]. If he did go home, it was only for a brief visit. In his letter to King James, Margeret mentioned that "Prince Radziwiłl" was willing to ride to the rescue if things went wrong during an English invasion of north Russia. His reference to "Prince Radziwiłł" explains what happened to Captain Margeret. Sometime during 1612 he entered the service of Janusz Radziwiłł (15791620), an immensely wealthy Lithuanian magnate and prince of the Holy Roman Empire who was the chief protector of Protestantism in Eastern Europe. Prince Radziwiłł worked closely with Johann Sigismund, the Elector of Brandenburg, and as Polish intervention in Russia deepened they did what they could to stop King Sigismund from conquering that country. Not surprisingly, they frequently turned for help to their good friend James I of England [31, p. 288, note 42; 40, p. 11, 27, 141-142, 151, 246, 251, 270, note 88, 289, note 106]. Janusz Radziwiłł was horrified by Sigismund III's success in Russia, and the Polish government in turn kept a watchful eye on him as a possible threat to its conquest. In 1609 Sigismund accused Prince Radziwiłł of plotting to assassinate him, and frequent contact between Radziwiłł and King James was regarded with deep suspicion by the Polish court [14, s. 295-296; 40, p. 27, 139]. Janusz Radziwiłł was extremely knowledgeable about Polish intervention in Russia, and he kept James and Johann Sigismund well informed about it. At some point Prince Radziwiłł met and hired Captain Margeret, who may have accompanied him to England in December 1612 to meet with King James. At that time James was filled with excitement about the possibility of establishing a protectorate over north Russia [20, p. 470; 40, p. 289, note 107]. Radziwiłł discussed the English project with Margeret and encouraged him to write a letter to James offering support and expert advice. As Prince Radziwiłł's protégé, Captain Margeret was taken seriously by the king of England.

Captain Margeret remained in Janusz Radziwiłł's service from 1612 until Radziwiłł's death in 1620. Margeret served as Prince Radziwiłł's trusted lieutenant, resident Russia expert, intelligence officer, military affairs adviser, financial affairs adviser, bailiff, and general fixer. Captain Margeret and Prince Radziwiłł got along very well. Both men were energetic soldiers, devout Calvinists, admirers of Tsar Dmitrii, and determined foes of Sigismund III. By the time Margeret entered his service, Prince Radziwiłł was already undermining Sigismund's efforts to conquer Russia by supporting the cause of thousands of unpaid soldiers returning from previous campaigns there. Large bands of these disgruntled veterans wandered across Poland-Lithuania from 1612 to 1614, robbing Polish gentlemen, "overtaxing" peasants and shopkeepers, and interfering with ordinary revenue collection. Known as "confederates," they seriously disrupted King Sigismund's recruiting efforts for military campaigns in Russia. Prince Radziwiłł secretly subsidized hundreds of confederate commanders, distributing 500 zloty to each colonel and 300 zloty to each captain. That cost Radziwiłl an astonishing 180,000 zloty, but the strategy paid off. It helped force Sigismund to delay invading Russia from 1613 to 1614 [6, s. 255-259; 25, p. 2]. Radziwiłł hired Captain Margeret in part to help deal with the logistics of subsidizing hundreds of confederate officers. Margeret was the right man for the job; he knew many of the confederate officers personally. At the same time Janusz Radziwiłl was helping confederate officers, his younger brother, Krysztof Radziwiłł (1585-1640), led the opposition in the Polish Sejm (parliament) to Sigismund's efforts to conquer Russia. Senator Radziwiłł succeeded in getting the Sejm to deny 
funding for Sigismund's planned invasion of Russia in 1613 [80, p. 410, note $10 ; 123$, p. 102-107].

Janusz Radziwiłł regarded Captain Margeret as a "faithful servant" and valuable asset. Margeret proved to be an excellent intelligence officer, often working closely with the staff of the elector of Brandenburg. Radziwiłł sent him on several missions to England to confer with King James about the condition of Protestantism in Eastern Europe and to gather information and documents for Radziwiłł's archive [80, p. 403-405, 407-408; 89, p. 507-508, 508, notes 6-7; 119, p. 125, 144-145, 191-192]. When King Gustav II Adolf (r. 1611-1632) of Sweden lifted the siege of Pskov in October 1615 and began negotiating a peace treaty with Tsar Mikhail, many Protestants in Poland-Lithuania (including Radziwiłl and Margeret) celebrated. Hostility to Sweden for grabbing Russian territory and supporting the usurper Tsar Vasilii quickly gave way to strong support. Protestant subjects of Sigismund III began providing the Swedish government with reliable intelligence about Polish military plans and operations. Prince Radziwiłł and Captain Margeret concluded that the best way to protect Protestants in PolandLithuania and elsewhere in Eastern Europe was to support the king of Sweden as the champion of international Protestant resistance to the Counter-Reformation. In late 1615 Margeret secretly contacted his old nemesis, the Swedish general Jacob De la Gardie, with an offer from Janusz Radziwiłł to provide Gustav Adolf with up-to-date intelligence and expert military advice for use against Sigismund III. General De la Gardie was extremely pleased and told Swedish Chancellor Axel Oxenstierna that Captain Margeret should receive a secret pension. King Gustav Adolf gave Margeret a very expensive gold chain as a reward for providing useful information about military matters. Over the next several years Margeret provided the king of Sweden with valuable reports. Gustav Adolf declared that his collaboration with Prince Radziwiłł and Captain Margeret was one of "mutual advantage" [89, p. 509-511, 509, note 8 , 511, note 10]. Perhaps at the prompting of Janusz Radziwiłł, in 1617 the Swedish government secretly reached out to Janusz's younger brother, Krzysztof, another highly visible champion of Protestantism; but Krzysztof Radziwiłł rejected the Swedish overture and remained faithful to Sigismund III [43, p. 116].

By 1619 Captain Margeret had developed a wide network of contacts, and he shared military, diplomatic, and political information with King James and other Protestant rulers. By then Margeret was also providing information to the French government; Catholic France had recently become an invaluable ally in Protestant Europe's struggle against the Counter-Reformation. Margeret became a close friend of the French ambassador to the Holy Roman Empire, who relayed Margeret's information to the future Cardinal Richelieu, who in turn put it to good use [13, p. 91-94, 98; 71, p. xix-xxi, xxvi; 98, p. 18288; 130, p. 347]. Margeret's correspondence in this period shows that he had become a trusted financial adviser to Janusz Radziwiłł and had many influential colleagues in Poland-Lithuania, Brandenburg-Prussia, the Palatinate, and elsewhere in Germany. Margeret was comfortable dealing with treasury officials and bankers, and he still maintained an interest in the fur trade [13, p. 91-98, 124-26; 71, p. x, xix, xxvi; 80 , p. 395-403]. During summer 1620 Prince Radziwiłł sent Margeret to England with gifts for King James, including fine horses and nearlyextinct "Ure-oxen" (aurochs) that still thrived on Radziwiłł's vast estates in Lithuania [80, p. 403405, 407-408; 119, p. 191-192]. Janusz Radziwiłł died in December 1620. Captain Margeret dutifully continued to serve Radziwiłl's widow, Princess Sophia, and her baby son, Boguslav. He accompanied them to England where they could live without fear under King James' protection. Margeret returned to Lithuania by June 1621 and reported to Janusz's brother, Krzysztof Radziwiłł, who was by then the commander of the fortress of Riga. Krzysztof treated Janusz's "old lieutenant" with courtesy and respect, and he authorized reimbursement of the hefty expenses Margeret had incurred while escorting Princess Sophia to England [89, p. 508].

Jacques Margeret had faithfully served Prince Janusz Radziwiłł for eight years. At that point he could have retired to a life of leisure, as some historians mistakenly concluded $[71, \mathrm{p} . \mathrm{x}$, xxi, xxvi; 72, p. 6]. Instead, Huguenot Margeret saw it as his duty to continue fighting against Sigismund III and the Counter-Reformation. Tired of being on the sidelines, he looked for an 
opportunity to serve once again as an active-duty field officer. In early August 1621, Margeret crossed the frontier into Livonia and headed directly to the camp of the Swedish army preparing to attack Polish-controlled Riga. King Gustav Adolf warmly welcomed Captain Margeret, immediately promoted him to the rank of general, and gave him command of thousands of soldiers about to lay siege to Riga fortress. Gustav Adolf launched his attack on August 17, 1621. The "enemy" commander of Riga fortress was, of course, Prince Krzysztof Radziwiłl, who must have been very surprised to receive an intelligence report about Swedish forces that mentioned the arrival of a new senior officer, "the Frenchman Margeret commanding the infantry" [43, p. 102$104 ; 89$, p. $511 ; 105$, p. 42]. Vastly outnumbered and outgunned, Radziwiłł honorably surrendered Riga after only a few weeks. It is doubtful that Prince Radziwiłł and General Margeret ever met during the siege.

King Gustav Adolf's capture of Riga "began the stunning series of victories" that turned Lutheran Sweden into a great power and helped put an end to the Counter-Reformation [43, p. 103]. Jacques Margeret played an important, even heroic, part in the early history of that international Protestant success story. After the siege of Riga, however, Margeret disappeared from the historical record. We do not know if he died in battle, followed Gustav Adolf into Germany, or returned home to France. Future researchers will almost certainly find additional information about Jacques Margeret. Interest in the remarkable Huguenot soldier and his important book is strong and growing, and there are still many relevant documents waiting to be examined in European archives ${ }^{29}$.

\section{NOTES}

${ }^{1}$ I dedicate this essay to my friend and colleague, Igor Olegovich Tyumentsev, who has taught me more about the Time of Troubles than anyone except Ruslan Grigor'evich Skrynnikov. I also wish to take this opportunity to thank Hanna Mazheika, Fabienne Queyroux, Pierre Gonneau, and Mark Heleniak for their assistance on this project.

${ }^{2}$ [76; 78]. I have not seen the second edition of Sostoianie Rossiiskoi Derzhavy, but a third edition was published in St. Petersburg in 1859. Ustrialov also published his translation of Margeret's book in part 3 of his collection of foreign accounts (1831-1834) [121], Margeret's account appears in vol. 3. The second edition of Skazaniia sovremennikov was published in 3 vols (1834-37) [122], with Margeret's account appearing in vol. 3. The third edition of Skazaniia sovremennikov was published in 2 vols (1859) [123], with Margeret's account appearing in vol. 1. All references to Skazaniia sovremennikov o Dmitrii Samozvantse in this essay are to the third edition [123].

${ }^{3}$ The title page implies that the editor, I.I. Borozdin, was the translator, but Nikolai Ustrialov is identified as the translator on page 8 of the introduction.

${ }^{4}$ J.T. Alexander, "Translator's Introduction" [101,p. xii].

${ }^{5}$ Catherine Depretto published a positive review in 2010 [24]. Maureen Perrie published a positive review in 2009 [96].

${ }^{6}$ Oleg Nozdrin mistakenly wrote that Jacques Margeret became a soldier only after being accused of being a Huguenot [89, p. 505].

${ }^{7}$ Margeret refers to the battle as the battle of Agria, mistakenly placing it in 1595 [69, p. 2; 73, p. 11; 85, p. 479].

${ }^{8}$ Captain Margeret's contemporaries referred to him as "Jacques," "Jacob," "Jakob," "Iakov," or "Iacobus." Even Berelowitch admits there is no record of anyone ever calling him "Étienne" [8, p. 457-458; 19, p. 54; 21, vol. 14, p. 492; 22 , vol. 16, p. 348; 71, p. iv, viii; 80, p. 265, 274-276; 81, p. 83-84, 117; 98, p. 193-194; 108, livre 2, p. 154; 112, col. 116; 123. vol. 1, p. xii].

${ }^{9}$ Guillaume Margeret's younger brother, Chrétien Margeret, is referred to as Captain Margeret's "uncle" in the "Privilege du Roy" of the second edition of Margeret's book [70, p. 177]. See also "Genealogicheskaia tablitsa roda Marzheretov" [80, p. 465-466].

${ }^{10}$ More than one historian has been confused by the sub-title of Margeret's book. Richard Hellie and William Reger thought Margeret was serving in Russia during the 1590s based on the sub-title of Margeret's book [46, p. 169, 357, note 77; 107, p. 236]

${ }^{11}$ Some historians mistakenly claimed that Margeret served as captain of Tsar Boris Godunov's bodyguard [9, p. 301,$313 ; 55$, p. $20 ; 123$, vol. 1, p. 237-238].

${ }_{12}$ Pushkin's literary license allowed him to move the battle from Dobrynichi in January 1605 to Novgorod Severskii in December 1604.

${ }_{13}$ Jacques-Auguste de Thou and Jean Richer erred in claiming that the first company of Tsar Dmitrii's bodyguard was composed of 100 Frenchmen. Their error is repeated by André Berelowitch [9, p. 313, note 62;21, vol. 14, p. 492; 108, livre 2, p. 154].

${ }^{14}$ Nazarov implausibly suggested that Margeret was not ill on the night of the assassination but 
skipped the tsar's wedding and left Moscow to visit one of his estates [85, p. 482-483].

${ }^{15}$ Chevreul incorrectly claimed that Margeret was financially ruined by Tsar Dmitrii's assassination, implying that Margeret was forced to return to France to make a financial recovery [71, p. iv]. That appears to have been a misreading of de Thou [21, vol. 14, p. 504].

${ }^{16}$ Use of a scribe is suggested by inconsistencies in orthography within Margeret's book, by inconsistencies in spelling between the book and Margeret's later writings, and by occasional digressions and asides in Margeret's narrative [33, p. 12, 208, note 55].

${ }_{17}$ Perhaps the most compelling evidence that Margeret prepared a rough draft of at least part of his book before returning to France is the sudden break in the text between Margeret's narrative of recent Russian history and the middle section of the book that describes the tsar's government, military forces, state revenue, the Russian Orthodox Church, and Russian society and culture [69, p. 8(v), 29(v); 73, p. 20,52].

${ }^{18}$ Friedrich von Adelung mistakenly claimed that Margeret borrowed material from Sigismund von Herberstein's famous account of Russia published in the mid-sixteenth century; his error was repeated by later scholars [1, s. 22; 4, p. 29-30; 61, p. 202-230; 102, p. 140-141, 146].

${ }_{19}$ Without realizing it, the editors of Sostoianie rossiiskoi imperii made use of the original copy of Estat de l'Empire de Russie that Captain Margeret presented to Henri IV in 1607. The book's cover is richly adorned with fleurs-de-lys and Henri IV's coat-of-arms, and the title page bears the stamp of the old Royal Library. The editors mistakenly claimed that the presentation copy was owned by the Margeret family and was not deposited in the royal library until 1668. They also jumped to the conclusion that handwritten corrections in the margins of the king's copy were made by Margeret personally [80, p. 8-10, 23-24, 36, note 40].

20 Jacques Margeret's relationship with the Saltykov family has been underappreciated. Margeret may have been a close associate of Mikhail Saltykov and his son Ivan. They served together as early as 1603 . All three participated in the campaign against the pretender Dmitrii. Russian sources accused Mikhail Saltykov of treason for sabotaging the siege of Kromy; Margeret's book is the only source that does not condemn Saltykov. Like Margeret, the Saltykovs remained loyal to Tsar Fedor until he was overthrown. Mikhail Saltykov worked in the Posol'sky prikaz with Margeret's expert informant, Afanasii Vlas'ev. The Saltykovs and Captain Margeret opposed the usurper Vasilii Shuiskii and served "Tsar Dmitrii" in Tushino. Margeret accompanied Mikhail Saltykov and other Tushinite dignitaries when they traveled to the Smolensk siege camp of Sigismund III to offer their loyalty to "Tsar Władysław" and to negotiate for land and peasants. Margeret and the Saltykovs participated in the battle of Klushino and the march on Moscow. Margeret and Mikhail Saltykov worked together in the pro-Władysław government, and they received generous votchina estates at the same time. Margeret accompanied Mikhail Saltykov to Warsaw in 1611 when they were summoned by King Sigismund III [36, p. 185 $188,197,210,394,406,409,413 ; 62$,p. 60-61, 71; 73,p. 66, 158 , note 217,159 , note $224 ; 80$, p. 365 , note $54 ; 100$, p. $254-256,264 ; 118$, p. $1-3 ; 123$, vol. 2 , p. 46-47; 130, p. 250-251,267].

${ }^{21}$ The text of the votchina grants received by Captain Margeret from Sigismund III is remarkably similar to the text of grants issued by the second pretender Dmitrii [57, p. 326-327; 130, p. 262-263].

${ }_{22}$ Margeret's huge votchina was located in the taiga on prime real estate for timber and furs, about 250 kilometers south of Arkhangel'sk. His votchina consisted of over 1000 square kilometers of forested hills and plains, two rivers, many streams, and twenty kilometers of frontage on the Northern Dvina River. One of the villages had a tavern. On this region see Janet Martin [75, note 119, p. 139-142].

${ }^{23}$ Unicorn horn was considered a sovereign antidote to poison in early modern Europe. The tsar's unicorn-horn staff was made of narwhal tusk (tooth).

${ }^{24}$ Chevreul erred in claiming that Margeret resigned from the royal council to lead a life of leisure [71,p. ix].

${ }^{25}$ Ruslan Skrynnikov erred in claiming that Margeret moved to Holland and that his stories of the riches to be had in Russia inspired Flodorf's project [114, p. 207-208].

${ }^{26}$ François Lesquaire's bizarre story confused many historians, some of whom even mistook him for Jacques Margeret [49, p. 208; 80, p. 10-11, 313-326, 374].

${ }^{27}$ Margeret sent his letter to James soon after the March 1613 meeting of the Polish Sejm. Nazarov incorrectly claimed that Margeret sent his letter in late 1613 , basing that claim on information in the letter about the new tsar. Nazarov assumed the letter referred to Tsar Mikhail's coronation in summer 1613, but it actually referred to Mikhail's election in February 1613. The Russian ambassador brought news of the election to Warsaw in late March 1613 [77, p. 410, note 10; 113, p. 402,406$]$.

${ }^{28}$ Margeret did not travel to north Russia only to be turned away by Russian authorities, as some historians claimed [44, p. 387]. Ruslan Skrynnikov implausibly claimed that Margeret "expected to be welcomed with open arms" by the Russians [114,p. 208].

29 The largest collection of archival sources concerning the Radziwiłł family is held in Archiwum Glównym Akt Dawnych in Warsaw: Archiwum Warszawskie Radziwitłów. Jacques Margeret's name appears on many documents from the period 1614-1620. 


\section{REFERENCES}

1. Adelung F. Kritisch-literärische Übersicht der Reisenden in Russland bis 1700. In 2 Bd. Bd. 2. Saint Petersburg, Eggers \& Company, 1846. $430 \mathrm{~s}$.

2. Akty istoricheskie, sobrannye i izdavaemye Arkheograficheskoiu komissieiu. In 5 vols. Vol. 3. Saint Petersburg, Tipe of. II-nd Branch Own E. I. V. Office, 1841.538 p. (in Russian).

3. Akty, otnosiashchiesia $k$ istorii Zapadnoi Rossii. In 5 vols. Vol. 4. 1588-1632. Saint Petersburg, Tipe of. E. Pratz, 1851. VIII + 526 p. (in Russian).

4. Alpatov M.A. Russkaia istoricheskaia mysl' $i$ Zapadnaia Evropa: XVII - pervaia chetvert' XVIII veka. Moscow, Nauka, 1976. 455 p. (in Russian).

5. Andrusiewicz A. Krwawa dekada 1602-12. Krakow, Wydawnictwo Literackie, 2013. $560 \mathrm{~s}$.

6. Archiwum Domu Radziwitłów. Kraków, nakł. Księcia Antoniego Radziwiłła, 1885. $295 \mathrm{~s}$.

7. Atkinson G. Les nouveaux horizons de la renaissance française. Paris, E. Droz, 1935.502 p.

8. Berelovich A. Kapitan Marzheret vo frantsuzskikh arkhivakh. Marzheret Zh.; Berelovich A., Nazarov V.D., Uvarov P.Yu., eds. Sostoianie rossiiskoi imperii: Zh. Marzheret $v$ dokumentakh $i$ issledovaniiakh. Moscow, Iazyk slavianskikh kul'tur, 2007, pp. 446-476. (in Russian).

9. Berelowitch A. Les origines du capitaine Margeret. L'influence française en Russie au XVIIIe siècle. Paris, Institut d'études slaves, 2004, pp. 301-321.

10. Berry L.E., ed. The English Works of Giles Fletcher, the Elder. Madison, Univ. of Wisconsin Press, 1964. 546 p.

11. Beskrovnyi L.G. Ocherki po istochnikovedeniia voennoi Rossii. Moscow, Publishing House of the Academy of Sciences of the USSR, 1957. $452 \mathrm{p}$. (in Russian).

12. Bodin J. Method for the Easy Comprehension of History. New York, Columbia University Press, 1945. $\mathrm{xxix}+380 \mathrm{p}$.

13. Boldakov I.M.; Sheremetev S.D., ed. Sbornik materialov po russkoi istorii nachala XVII veka. Saint Petersburg, 1896. 153 p. (in Russian).

14. Borowy W. Anglicy, Szkoci i Irlandczycy w wojsku polskom za Zygmunta III. Studia z Dziejów Kultury Polskiej. Warszawa, Gebethner i Wolff, 1949. S. 293-313.

15. Braudel Fernand. The Mediterranean and the Mediterranean World of Philip II. In 2 vols. New York, Harper and Row, 1976.

16. Budziłło Józef. Historia Dymitra fałszywego. Kubala M., Ściężor T., eds. Moskwa w rękach Polakow. Krakyw, Platan, 2005.

17. Burrow D. Food at the Russian Court and the Homes of the Imperial Russian Elite, Sixteenth to midNineteenth Centuries. Daniëlle DeVooght, ed., Royal
Taste: Food, Power and Status at European Courts after 1789, Routledge, 2011, pp. 87-110.

18. Bussov C. Moskovskaia khronika, 15841613. Moscow, Saint Petersburg, Publishing House of the Academy of Sciences of the USSR, 1961. 400 p. (in German and in Russian).

19. Bussow C. The Disturbed State of the Russian Realm. Montreal, McGill-Queen's University Press, 1994. xliv $+244 \mathrm{p}$.

20. Calendar of State Papers and Manuscripts, Relating to English Affairs, Existing in the Archives and Collections of Venice, and in other Libraries of Northern Italy. Part XII [1610-13]. London, His Majesty's Stationery Office, 1905.

21. De Thou Jacques-Auguste. Histoire universelle. In 16 vols. London, 1740.

22. De Thou Jacques-Auguste. Historia sui temporis. In 20 vols. Paris, 1608.

23. De Xivrey Berger, ed. Recueil des lettres missives de Henri IV. In 9 vols. Vol. 7. 1606-1610. Paris, Imp. Royale, 1858. 956 p.

24. Depretto S. Review of Zhak Marzheret, Sostoianie rossiskoi imperii, 2010, vol. 81, nos. 2-3, pp. 365-368.

25. Deutsches Zentralarchiv Abteilung II, Merseburg, rękopis 6, no. 28.

26. Dolinin N.P. K izucheniiu inostrannykh istochnikov o krest'ianskom vosstanii pod rukovodstvom I.I. Bolotnikova 1606-1607. Mezhdunarodnye sviazi Rossii do XVII v. Moscow, Publishing House of the Academy of Sciences of the USSR, 1961, pp. 462-490. (in Russian).

27. Drouot H., Gros L. Recherches sur la Ligue en Bourgogne. Dijon, Damidot frères, 1914. 237 p.

28. Drouot H. Après la paix de Nemours, l'affaire d'Auxonne (1585-1586). Annales de Bourgogne, 1929, vol. 1.

29. Drouot H. Mayenne et la Bourgogne: Étude sur la Ligue (1587-1596). Dijon, A. Picard, 1937. 525 p.

30. Dunning Ch., Emerson C., Fomichev S., Lotman L., Wood A. The Uncensored Boris Godunov: The Case for Pushkin's Original Comedy. Madison WI, University of Wisconsin Press, 2006. 578 p.

31. Dunning Ch. A 'Singular Affection' for Russia: Why King James Offered to Intervene in the Time of Troubles. Russian History / Histoire Russe 34, 2007, nos. 1-4, pp. 279-302.

32. Dunning Ch. A Letter to James I Concerning the English Plan for Military Intervention in Russia. The Slavonic and East European Review, 1989, vol. 67, no. 1, pp. 94-108.

33. Dunning Ch. Jacques Margeret's State of the Russian Empire and Grand Duchy of Muscovy: A Translation. Ph.D. diss. Boston College, 1976. 258 p.

34. Dunning Ch. James I, the Russia Company, and the Plan to Establish a Protectorate over North 
Russia. Albion: A Quarterly Journal Concerned with British Studies, 1989, vol. 21, no. 2, Summer, pp. 206-226.

35. Dunning Ch. Quand un Français redécouvrait la Russie. Revue Historique, 1984, t. 272, fasc. 2 (552), Octobre-Décembre, pp. 331-351.

36. Dunning Ch. Russia's First Civil War: The Time of Troubles and the Founding of the Romanov Dynasty. University Park PA, Pennsylvania State University Press, 2001. 657 p.

37. Dunning $\mathrm{Ch}$. The Richest Place in the World: An Early Seventeenth Century English Description and Military Assessment of Solovetskii Monastery. Rude \& Barbarous Kingdom Revisited: Essays in Russian History and Culture in Honor of Robert $O$. Crummey. Bloomington (IN), Slavica Publishers, 2008, pp. 309-325.

38. Dunning Chester. The Use and Abuse of the First Printed French Account of Russia. Russian History /Histoire Russe, 1983, vol. 10, pt. 3, pp. 357-380.

39. Dunning Ch. Tsar Dmitrii's Bellicose Letter to King Karl IX of Sweden. Slavonic and East European Review, 2009, vol. 87, no. 2, April, pp. 322-336.

40. Fedorowicz J. K. England's Baltic Trade in the Early Seventeenth Century. Cambridge, Cambridge University Press, 1980. 334 p.

41. Fletcher G. Of the Russe Common Wealth. London, Printed by T.D. for Thomas Charde, $1591.550 \mathrm{p}$.

42. Floria B.N. Russko-pol'skie otnosheniia $i$ baltiiskii vopros $v$ kontse XVI - nachale XVII v. Moscow, Nauka, 1973. 224 p. (in Russian).

43. Frost R.I. The Northern Wars: War, State and Society in Northeastern Europe, 1558-1721. London, Longman, 2000. $401 \mathrm{p}$.

44. Gamel' (Hamel) I.; Leigh J.S., transl. England and Russia. London, 1854. 422 p.

45. Glozier M., Onnekink D., eds. War, Religion and Service: Huguenot Soldiery, 1685-1713. Burlington VT, Ashgate, 2007. 296 p.

46. Hellie R. Enserfment and Military Change in Muscovy. Chicago, University of Chicago Press, $1971.442 \mathrm{p}$.

47. Howe S. E. The False Dmitri. London, Williams \& Norgate, 1916.239 p.

48. Ikonnikov V.S. Snosheniia Rossii s Frantsiei, XVI-XVIII vv.: Istoricheskii ocherk. [Kiew], Typ. I.N. Kushnerev and $\mathrm{K}^{\circ}$ in Moscow, Kiev Branch, Kiev, 1893.62 p. (in Russian).

49. Jansson M., Rogozhin N, eds. England and the North: The Russian Embassy of 1613-1614. Philadelphia, American Philosophical Society, 1994. xxxvi + 236 p.

50. Joukovskaia A.A Living Law: Divorce Contracts in Early Modern Russia. Kritika, 2017, vol. 18, no. 4, Fall, pp. 661-681.

51. Karamzin N.G. Pis'ma N.M. Karamzina $k$ I.I. Dmitrievu. Saint Petersurg, Type of. Imp. Akad. of science, 1866. 727 p. (in Russian).
52. Karamzin N.G. Istoriia gosudarstva Rossiiskago. In 12 vols. Vol. 11. Saint Petersburg, Tip. of N. Gretsa, 1824. 321, [1], 154, [2] p. (in Russian).

53. Kleimola A. Cultural Convergence: The Equine Connection Between Muscovy and Europe. Karen R., Treva J.T., eds. The Culture of the Horse: Status, Discipline, and Identity in the Early Modern World. US, Palgrave Macmillan, 2005, pp. 45-62.

54. Kleinclauz A. Histoire de Bourgogne. Geneva, Slatkine, 1976. 453 p.

55. Kliuchevskii V.O. Skazaniia inostrantsev o Moskovskom gosudarstve. Petrograd, 1st State Printing House, 1918. 332 p. (in Russian).

56. Kopanev A.I., Man'kov A.G., eds. Vosstanie I. Bolotnikova. Dokumenty i materialy. Moscow, Socjekgiz, 1959. 455 p. (in Russian).

57. Koretski V.I. Formirovanie krepostnogo prava $i$ pervaia krest'ianskaia voina $v$ Rossii. Moscow, Nauka, 1975. 390 p. (in Russian).

58. Kostomarov N.I. Sobranie sochinenii. $V 8 t$. T. 2. Smutnoe vremia Moskovskogo gosudarstva $v$ nachale XVII stoletiia. Saint Petersburg, Tip. M.M. Stasyulevich, 1904. 672 p. (in Russian).

59. Kozulin V.N. Obraz Rossii i russkikh v sochinenii Zhaka Marzhereta. Izvestiia Altaiskogo gosudarstvennogo universiteta, 2017, no. 5, pp. 139146. (in Russian).

60. Kulakova I.P. Vosstanie 1606 g. v Moskve i votsarenie Vasiliia Shuiskogo. Sotsial'noekonomicheskie problemy istorii SSSR: Sbornik statei. Moscow, MSU, 1985, pp. 35-50. (in Russian).

61. Limonov Iu.A. Kul'turnye sviazi Rossii s evropeiskimi stranami $v X V-X V I I v v$. Leningrad, Nauka, 1978. 272 p. (in Russian).

62. Liseitsev D.V. Posol'skii prikaz v epokhu Smuty. Vol 1. Moscow, Institute of Russian History, Russian Academy of Sciences, 2003. 264 p. (in Russian).

63. Liseitsev D.V. Prikaznaia sistema Moskovskogo gosudarstva v epokhu Smuty. Moscow; Tula, Grif and K० 2009.788 p. (in Russian).

64. Liseitsev D., Bland R. Reconstructing the Late Sixteenth- and Seventeenth-century Muscovite State Budget. Kritika, 2016, vol. 17, no. 1, Winter, pp. 5-26.

65. Liubimenko I. A Project for the Acquisition of Russia by James I. The English Historical Review, 1914, vol. 29, pp. 246-256.

66. Liubimenko I. Les Relations commerciales et politiques de l'Angleterre avec la Russie avant Pierre le Grand. Paris, Champion, 1933. 310 p.

67. Mansuy A. Le Monde slave et les classiques français aux XVIe-XVIIe siècles. Paris, H. Champion, 1912. $493 \mathrm{p}$.

68. Marchocki M. Historia moskiewskiej wojny prawdziwa. Kubala M., Ściężor T., eds. Moskwa w rękach Polakow. Krakyw, Platan, 2005, s. 19-138. 
69. Margeret J. Estat de l'Empire de Russie et Grand Duché de Moscovie. Avec ce qui s'y est passé de plus memorable \& Tragique, pendant le regne de quatre Emperours: à sçavoir depuis l'an 1590. iusques en l'an 1606. en Septembre. Paris, M. Guillemot, 1607.54 p.

70. Margeret J. Estat de l'Empire de Russie et Grand Duché de Moscovie. Paris, Iacques Langlois, $1669.180 \mathrm{p}$.

71. Margeret J.; Chevreul H., ed. Estat de l'Empire de Russie et Grand Duché de Moscovie. Paris, L. Potier, $1860.127 \mathrm{p}$.

72. Margaret J. Estat de L'Empire de Russie et Grand Duché de Moscovie. Paris, Éditons du Genet, 1946. $141 \mathrm{p}$.

73. Margeret J.; Dunning Ch.S.L., transl. and ed. The Russian Empire and Grand Duchy of Muscovy: A Seventeenth-Century French Account. Pittsburgh (PA), University of Pittsburgh Press, 1983. $216 \mathrm{p}$.

74. Margolin S.L. Oborona russkogo gosudarstva ot tatarskikh nabegov v kontse XVI veka. Trudy Gosudarsvennogo istoricheskogo muzeia, 1948, iss. 20, pp. 3-28. (in Russian).

75. Martin J. Treasure of the Land of Darkness: The Fur Trade and its Significance for Medieval Russia. New York, Cambridge University Press, 1986. $277 \mathrm{p}$.

76. Marzheret Zh. Istoricheskie zapiski: per. s fr. Moscow, Type of. Lazarev Institute of Eastern Languages, 1830. 218 p. (in Russian).

77. Marzheret Zh.; Limonov Iu., ed. Rossiia nachala XVII v. Zapiski kapitana Marzhereta. Moscow, Institut istorii SSSR, 1982. 255 p. (in Russian).

78. Marzheret Zh.; Ustrialov N., transl. and ed. Sostoianie Rossiiskoi derzhavy $i$ Velikago kniazhestva Moskovskago. Saint Petersburg, Type of. Main Directorate for Communications, 1830. 163 p. (in Russian).

79. Marzheret Zh. Sostoianie Rossiiskoi derzhavy $i$ Velikago Kniazhestva Moskovskago. Moscow, "Pol'za", V. Antik and K, 1913. 104 p. (in Russian).

80. Marzheret Zh.; Berelovich A., Nazarov V.D., Uvarov P.Iu., eds. Sostoianie Rossiiskoi imperii: Zh. Marzheret $v$ dokumentakh i issledovaniiakh. Moscow, Yazyk slavianskikh kul'tur, 2007. 552 p. (in Russian).

81. Massa I. A Short History of the Beginnings and Origins of These Present Wars in Moscow under the Reign of Various Sovereigns down to the Year 1610. Toronto, University of Toronto Press, 1982. 235 p.

82. Massa I. Kratkoe izvestie o Moskovii v nachale XVII veka. Moscow, Socjekgiz, 1937.206 p. (in Russian).

83. Muliukin A.S. Priezd inostrantsev $v$ Moskovskom gosudarstve. Saint Petersburg, Type of "Trud", 1909. 292 p. (in Russian).
84. Murdock G. Calvinism on the Frontier 1600 1660: International Calvinism and the Reformed Church in Hungary and Transylvania. Oxford, Clarendon Press, 2000. 359 p.

85. Nazarov V.D. Kapitan Marzheret i Rossiia: metamorfozy sud'by odnogo naemnika. Marzheret Zh.; Berelovich A., Nazarov V.D., Uvarov P.Iu., eds. Sostoianie rossiiskoi imperii: Zh. Marzheret $v$ dokumentakh i issledovaniiakh. Moscow, Iazyk slavianskikh kul'tur, 2007, pp. 477-498. (in Russian).

86. Nazarov V.D. O datirovke 'Ustava ratnykh i pushechnykh del'. Voprosy voennoi istorii Rossii XVIII i pervoj poloviny XIX vekov. Moscow, Nauka, 1969, pp. 216-221. (in Russian).

87. Nemoevskii S. Zapiski Stanislava Nemoevskogo (1606-1608). Titov A.A., ed. Rukopisi slavianskie i russkie. Vyp. 6. Moscow, 1907, pp. 1-197. (in Russian).

88. Novyj letopisec. Polnoe sobranie russkikh letopisei. In 43 vols. Vol. 14. Saint Petersburg, The Publication of the Archaeographic Comiss, 1910, pp. 1154. (in Russian).

89. Nozdrin O.J. The Autumn of the Captain: Jacques Margeret's Last Mission. Russian History, 2014, vol. 41, iss. 4, pp. 505-511.

90. Nozdrin O.J. The Flodorf Project: Russia in the International Mercenary Market in the Early Seventeenth Century. Brian L. D. Warfare in Eastern Europe, 1500-1800. Leiden, Brill, 2012, pp. 109-118.

91. Olearius A. The Travels of Olearius in Seventeenth-Century Russia. Stanford (CA), Stanford University Press, 1967. 368 p.

92. Palitsyn Avraamii. Skazanie Avraamiia Palitsyna. Moscow, Publisher Academy of Sciences of the USSR, 1955. 348 p. (in Russian).

93. Paris L., ed. La Chronique de Nestor. In 2 vols. Paris, Heideloff et Campé, 1834-1835.

94. Parker G. The Limits to Revolutions in Military Affairs: Maurice of Nassau, the Battle of Nieuwpoort (1600), and the Legacy. Journal of Military History, 2007, vol. 71, no. 2, pp. 331-372.

95. Parrott D. Strategy and Tactics in the Thirty Years' War: The 'Military Revolution'. Clifford J.R., ed. The Military Revolution Debate, Colorado, Boulder, Westview Press, 1995, pp. 227-251.

96. Perrie M. Review: Marzheret Zh. Sostoianie Rossiiskoi imperii. Zh. Marzheret v dokumentakh i issledovaniiakh. (Teksty, kommentarii, stat'i). The Slavonic and East European Review, 2009, vol. 87, no. 3, July, pp. 555-557.

97. Phipps G. Britons in Seventeenth-Century Russia: A Study in the Origins of Modernization. Ph.D. diss. Univ. of Pennsylvania, 1971.

98. Pirling P. Iz Smutnago vremeni. Stat'i $i$ zametki. Saint Petersburg, A.S. Suvorin, 1902. 270 p. (in Russian). 
99. Platonov S.F.; Wieczynski J.L., transl. and ed. Moscow and the West. Hattiesburg (Miss.), Academic International, 1972. xx, 171 p. Russian Series, vol. 9.

100. Platonov S.F. Ocherki po istorii Smuty $v$ Moskovskom gosudarstve XVI-XVII vv. Saint Petersburg, Type of. M.A. Alexandrov, 1910. 642 p. (in Russian).

101. Platonov S.F.; J.T. Alexander, transl. The Time of Troubles: A Historical Study of the Internal Crisis and Social Struggle in Sixteenth-and SeventeenthCentury Muscovy. Lawrence, The University Press of Kansas, 1970. xvii, 197 p.

102. Poe M. “A People Born to Slavery”: Russia in Early Modern European Ethnography, 1476-1748. Ithaca (NY), Cornell University Press, 2000. 293 p.

103. Poletaev A.B. Preface. Physiologic Autoimmunity and Preventive Medicine. Moscow, 2013,pp. VIII-IX.

104. Purchas S. Hakluytus Posthumus, or Purchas His Pilgrimes. In 20 vols. Glasgow, University Press by Robert Maclehose \&Company LTD, 1905-1907.

105. Radziwiłł K. Sprawy wojenne i polityczne, 1621-1633. Paris, 1859. 713 p.

106. Razin E. Istoriia voennogo iskusstva. In 3 vols. Vol. 3. Moscow, Voenizdat, 1957. 654 p. (in Russian).

107. Reger W. M. IV. European Mercenary Officers and the Reception of Military Reform in the Seventeenth Century Russian Army. Kotilaine Ja., Poe M., eds. Modernizing Muscovy: Reform and Social Change in Seventeenth-Century Russia. London, Routledge, 2004, pp. 223-246.

108. Richer J., Mercure François. En 25 volumes. Paris, Estienne Richer, 1611-1648.

109. Rodionova Iu.R. Russkoe voisko XVII veka po svedeniiam frantsuzskogo kapitana-naemnika Zhaka Marzhereta. Vestnik molodykh uchenykh $i$ spetsialistov Samarskogo gosudarstvennogo universiteta, 2016, no. 1, pp. 86-89. (in Russian).

110. Rogozhin N.M., ed. Posol'skaia kniga po sviaziam Rossii s Angliei 1613-1649 gg. Moscow, Institute of History, RAS, 1979. 244 p. (in Russian).

111. Russkaia istoricheskaia biblioteka. In 39 vols. Vol. 2. Saint Petersburg, Type of. br. Panteleyev, 1875. 656 p. (in Russian).

112. Russkaia istoricheskaia biblioteka. In 39 vols. Vol. 8. Saint Petersburg, Type of. F.G. Elkovsky and Co, 1884. 700 p. (in Russian).

113. Sbornik Imperatorskago Russkago istoricheskago obshchestva. In 146 vols. Vol. 142. Saint Petersburg, Type of. G. Lissner and D. Sobko, 1913. 804 p. (in Russian).

114. Skrynnikov R.G.; Graham H.F., ed. and transl. The Time of Troubles: Russia in Crisis, 1604-1618. Gulf Breeze (FL), Academic International Press, 1988. 325 p.
115. Smirnov I.I. Vosstanie Bolotnikova 16061607. Moscow, Gospolitizdat, 1951.588 p. (in Russian).

116. Sobranie gosudarstvennykh gramot $i$ dogovorov. In 4 vols. Vol. 2. Saint Petersburg, Type of. Selivanovsky, 1819.612 p. (in Russian).

117. Stout F.J. Exploring Russia in the Elizabethan Commonwealth: The Muscovy Company and Giles Fletcher, the Elder (1546-1611). Manchester, Manchester University Press. 2015. 288 p.

118. Sukhotin L.M. Chetvertchiki Smutnogo vremeni (1604-1617). Moscow, Society of History and Antiquities to enter the Russian at the Moscow University, 1912. 400 p. (in Russian).

119. Talbot C.H., ed. Res Polonicae Jacobo I Angliae regnante conscriptae ex archivis Londoniarum. Rome, 1962.

120. Trim D.J.B. The Huguenots and the European Wars of Religion, c.1560-1697: Soldiering in National and Transnational Context. Trim D.J.B., ed., The Huguenots: History and Memory in Transnational Context. Series: Studies in the History of Christian Traditions. Vol. 156. Leiden, Brill, 2011, pp. 153-192.

121. Ustrialov N., ed. Skazaniia sovremennikovo Dmitrii Samozvantse. In 5 Vols. Saint Petersburg, Type of. Imperial Russian Academy, 1831-1834. (in Russian).

122. Ustrialov N., ed. Skazaniia sovremennikovo Dmitrii Samozvantse. In 3 vols. Saint Petersburg, Type of. Imperial Russian Academy, 1834-1837. (in Russian).

123. Ustrialov N., ed. Skazaniia sovremennikovo Dmitrii Samozvantse. In 2 vols. Saint Petersburg, Type of. Imperial Russian Academy, 1859. (in Russian).

124. Vernadsky G. The Tsardom of Moscow. 15471682. In 2 vols. Vol. 1. New Haven, London, Yale University Press, 1969.873 p.

125. Videkind Io. Istoriia desiatiletnei ShvedskoMoskovitskoi voiny. Moscow, Pamjatniki istoricheskoj mysli, 2000. 652 p. (in Russian).

126. Vovina V.G. Patriarkh Filaret (Fedor Nikitich Romanov). Voprosy istorii, 1991, nos. 7-8, pp. 53-74. (in Russian).

127. Waliszewski K. La Crise revolutionnaire 1584-1614. Paris, Plon Nourrit et cie, 1906. 501 p.

128. Worth Dean S. The French Captain's Russian. Russian Linguistics, 1981, vol. 5, pp. 199-210.

129. Zagorovskii V.P. Belgorodskaia cherta. Voronezh, VSU, 1969.304 p. (in Russian).

130. Zhordaniia G. Ocherki iz istorii frankorusskikh otnoshenii kontsa XVI i pervoi poloviny $X V I I v$. In 2 Parts. Part 1. Tbilisi, Publishing house of Tbilisi University. 382 p. (in Russian).

131. Zolkiewsk S. Expedition to Moscow. London, Polonica Publications, 1959. 167 p. 


\section{Information about the Author}

Chester S. L. Dunning, Doctor, Emeritus Professor of History, Texas A\&M University, College Station, Texas, United States of America 77843-4236, c-dunning@tamu.edu, https://orcid.org/0000-0001$8655-3025$

\section{Информация об авторе}

Честер С. Л. Даннинг, доктор, заслуженный профессор истории, Техасский университет A\&M, г. Колледж-Стейшен, Техас, Соединенные Штаты Америки 77843-4236, c-dunning@tamu.edu, https://orcid.org/0000-0001-8655-3025 